7-1-2015

\title{
Ranking Law Schools, 2015: Student Aptitude, Employment Outcome, and Law Review Citations
}

\author{
Alfred L. Brophy \\ University of Alabama - School of Law, abrophy@law.ua.edu
}

Follow this and additional works at: https://scholarship.law.ua.edu/fac_working_papers

\section{Recommended Citation}

Alfred L. Brophy, Ranking Law Schools, 2015: Student Aptitude, Employment Outcome, and Law Review Citations, (2015).

Available at: https://scholarship.law.ua.edu/fac_working_papers/377

This Working Paper is brought to you for free and open access by the Faculty Scholarship at Alabama Law Scholarly Commons. It has been accepted for inclusion in Working Papers by an authorized administrator of Alabama Law Scholarly Commons. 


\title{
Ranking Law Schools, 2015: \\ Student Aptitude, Employment Outcome, Law Review Citations
}

Alfred L. Brophy ${ }^{1}$

\begin{abstract}
$\underline{\text { Abstract }}$
This essay builds on a paper released last year that ranked law schools on three variables: the median LSAT of entering students of the most recent class, the most recently available employment outcome for each school's graduates, and citations to each school's main law reviews over the past eight years. This paper updates that study with LSAT median data for the class entering in fall 2014, employment data for the class graduating in 2014 ten months after graduation, and the most recent law review citation data for 2007 through 2014. It studies 195 ABA approved law schools.

In addition to using more recent data, this study changes the method of combining those data. Where the last paper used simple ranks for each variable and averaged them, this study has a more granular approach to the data. It converts each school's median LSAT score and the percentage of students employed in full-time, permanent, JD-required jobs ten months after graduation (excluding school-funded positions and solo practitioners) to standard scores. In addition, given the dramatic differences in nuimber of law review citations among schools, it employs a common log transformation of law review citations and then converts the transformed scores to standard scores. The paper combines the first two scores to provide a two-variable ranking, and then combines all three variables to provide a three-variable ranking. The paper reports average scores for the three-variable ranking, thus permitting examination of how close schools are to each other. It also ranks the $195 \mathrm{ABA}-$ approved law schools in the United States (excluding the three schools in Puerto Rico) that U.S. News included in its rankings released in March 2015. And it compares the new, two- and three- variable rankings to the U.S. News provided ranks in March 2015. It identifies the schools that improve and decline the most with the new rankings.
\end{abstract}

1 Judge John J. Parker Distinguished Professor of Law, University of North Carolina-Chapel Hill. Contact the author at abrophy@email.unc.edu or 919.962.4128.

I would like to thank Bernard A. Burk, Stephen Ellmann, Daniel M. Filler, Gregg Polsky, Dana A. Remus, and Robert J. Smith for help. 
Nearly five years into the decline in law school applicants, there continues to be extraordinary concern among prospective students, legal educators, and the practicing bar about the state of legal education. These questions about the quality and content of education are occurring alongside longterm changes in the market for and delivery of legal services.

People considering attending law school are understandably focused on costs and employment prospects. Moreover, as the market for entry-level lawyers has continued to be poor, students want competitive edges. Common advice to prospective students is to attend well-regarded law schools. As competition increases to recruit students, schools are responding to prospective student preferences. The legal academic world is seeking the best students they can find and having the best job outcomes they can.

U.S. News \& World Report rankings include a number of factors. U.S. News weights especially heavily peer and lawyer/judge assessment; it also includes student quality as measured by LSAT scores of entering students, student selectivity as measured by percentage of applicants accepted, expenditures per student, bar pass rate, job outcome data, and even library resources. ${ }^{2}$ In response to the increasingly detailed job data that the ABA is collecting, U.S. News now includes employment outcomes as part of its ranking. ${ }^{3}$

While U.S. News' rankings include many variables, there is reason to focus attention on student quality and student outcome. ${ }^{4}$ The former is of concern to students because so much of the law school experience relates to interactions that students have with each other that the quality of other students ought to be an important factor for prospective students to consider. This paper uses the median LSAT scores of students entering in fall 2014, as reported by schools to the ABA, as its measure of

available at:

2 See Sam Flanigan and Robert Morse, Methodology: 2016 Best Law Schools Rankings, $\mathrm{http}$ //www.usnews.com/education/best-graduate-schools/articles/law-schools-methodology (reporting that "The U.S. News rankings of 198 law schools fully accredited by the American Bar Association are based on a weighted average of the 12 measures of quality described below. Data were collected in fall 2014 and early 2015.”).

${ }^{3}$ The placement success counted for $20 \%$ of the U.S. News 2016 rankings. See id. That included $14 \%$ for placement success of the class of 2013 at graduation and $4 \%$ for the placement success of the class of 2013 after nine months, as well as a small percentage, apparently, for a school's bar passage. It remains unclear how exactly U.S. News weighted "the number of grads employed in 43 of these different types of post-J.D. jobs, employment statuses and durations." Id. at page2 But we know that they gave full weight to full-time, long term employment in JD-required jobs unless those jobs were school-funded, in which case those were given less weight. It remains unclear how much less weight those jobs received.

${ }^{4}$ See, e.g., Laura Santoski, Another Law School Ranking System: Any Good?, available at http://blueprintprep.com/lsatblog/law-school-2/another-law-school-ranking-system-any-good/ 
student quality. The median LSAT tells about the revealed preferences of applicants; it also tells a great deal about the quality of the educational experience.

Employment outcome is of primary concern to prospective students and thus is central to the choice of a law school. There is an extensive literature on how to measure student employment outcomes. ${ }^{5}$ The literature addresses whether it is appropriate to include school-funded jobs and whether to include "JD advantaged" jobs in measuring employment outcome. ${ }^{6}$ To be sure, school funded positions can assist with the transition to practice. And many schools provide funding for such "bridge" positions. Table 1 lists the schools who employed 5\% or more of their 2014 graduating class in full-time, long-term J.D.-required positions. Prospective students comparing law schools may want to consider the assistance that those schools have provided to students in making the transition to practice. Nevertheless, there is also a good rationale for excluding those positions, because they may not always reflect the kinds of desirable jobs that are on par with full-time JD required jobs with law firms, public interest organizations, and government employers. Therefore, this paper settled on longterm, full-time JD-required jobs (omitting school-funded and solo practice) as the best single measure. ${ }^{7}$

5 See, e.g., Bernard A. Burk, What's New About the New Normal: The Evolving Market for New Lawyers in the 21st Century, 41 Florida State University Law ReVIEW 541-608 (2014) (discussing measures of employment outcomes, including "JD advantaged" positions).

${ }^{6}$ Law School Transparency provides extended discussion of the advantages and disadvantages of various measures of outcome. Their "employment score" measure is similar to one employed here, except that they exclude positions are solo practitioners. They also have a separate underemployment measure. http://www.lstscorereports.com/guides/Methodology/

7 There are problems with using a single variable as a measure of employment outcome, to be sure. The percentage of graduates employed in long-term, JD required jobs "does not in any way offer a complete picture of the choices available to graduates of Yale Law School, nor of the decisions they make. As a law school, we seek out and support students with extremely varied backgrounds and interests." Kelly Voight, Pulling Back the Curtain on the Latest US News Rankings, available at http:/www.law.yale.edu/studentlife/cdoprospectivestudentsemploystatsusnews.htm

Dean Voight explains further:

We provide tools to enable our students to pursue a multidisciplinary course of study and engage in intellectual pursuits of interest to them. It comes as no surprise to us, therefore, when many of our graduates turn down traditional legal employment for different types of opportunities. For example, several of our graduating students each year forego employment altogether to pursue advanced degrees, most often with the goal of being hired as a scholar by a law school. Seven graduates in the Class of 2013 (3.4\% of the Class) took that route. These graduates will undoubtedly secure meaningful employment upon completion of their degree programs. Additionally, several of our graduates each year choose professional positions, often involving policy, research or teaching, for which bar passage is not required and which do not 
The third and final variable used in this paper is citations to a law school's main law review over the period 2007-2014. This is designed to tell something about the intellectual orientation and culture of the school and to reveal something about the school's standing in the legal education community. ${ }^{8}$ U.S. News weights heavily reputation of law schools among other law faculty and among judges and lawyers. ${ }^{9}$ In place of those notoriously static and proprietary variables, this paper turns to citations to each school's main law review as a proxy for academic reputation. Previous research has shown that there is a high correlation between the U.S. News peer assessment scores and citations to schools' main law reviews. ${ }^{10}$ While many anonymous commentators criticized the inclusion of the scholarly output of a law school as a significant factor in ranking in the previous paper, ${ }^{11}$ citations offer one gauge that reflects the scholarly output and aspirations of a school. Moreover, that is not proprietary as U.S.

fit squarely in the ABA's definition of "JD Advantage." Six graduates in the Class of 2013 (3\% of the Class) accepted these types of positions. All of these graduates are fulfilling their professional goals and personal aspirations, just not within the strictures of the US News definition of "employed."

More importantly, beyond the data depicted on the ranked list of schools, this year US News is "discounting" the value of jobs funded by law schools and in some undisclosed way incorporating this "discount" into their overall ranking formula. We are extremely concerned that "discounting" year-long law school funded public interest fellowships will discourage law schools from offering these valuable opportunities to their graduates in future years.

Id. This is certainly a good explanation for why Yale Law performs less well than many of the schools that most of us would think are less good than Yale in student outcomes. However, there is reason to doubt whether such an explanation works for many schools beyond Yale.

8 See Alfred L. Brophy, The Emerging Importance of Law Review Rankings for Law School Rankings, 2003-2007, 78 U. CoLO. L. REV. 35 (2007).

9 U.S. News weights peer assessment as $25 \%$ of its ranking and lawyer/judge assessment as $15 \%$, for a total of $40 \%$ for what it calls the "quality assessment" scores. See Flanigan and Morse, supra note 2 .

10 Brophy, supra note 8.

11 See, e.g., Comment of Anon, June 20, 2014 at 10:17 AM, to Ranking Law Schools Based on LSAT, Employment Outcome, and Citations, available at:

http:/www.thefacultylounge.org/2014/06/ranking-law-schools-based-on-lsat-employment-outcome-an d-citations.html ('T'm still not sold on law school citations as a relevant proxy for a number of reasons."). 
News' peer and lawyer/judge assessment scores are; and citations are not as susceptible to manipulation as are the U.S. News peer and lawyer/judge assessment scores. Citations, moreover, are one popular tool for ranking - often, as in the work of Brian Leiter ${ }^{12}$ and Gregory Sisk, ${ }^{13}$ the citations are to the work of law faculty members. ${ }^{14}$ The present paper focuses on citations to recent issues of schools' main law reviews as a measure of school quality. ${ }^{15}$

\section{Describing the Variables: Median LSAT, Employment Outcome, and Law Review Citations}

This paper responds to several criticisms of the U.S. News law school rankings. First, there is the criticism that U.S. News uses too many different variables, some of which are irrelevant or distracting. The second criticism is that U.S. News focuses insufficient attention on employment outcomes. The third criticism is that U.S. News focuses too much on the largely static peer assessments that may poorly reflect the current quality of schools. In response to these criticisms, this paper turns to three variables. The first is a measure of student quality: median LSAT score of first year students entering in the fall of 2014. This was taken from data reported by law schools to the ABA and posted to their website. ${ }^{16}$ The second measure is outcome for graduates: the employment data for the class that graduated in spring 2014 that was reported to

12 See Brian Leiter, How to Rank Law Schools, 81 InD. L.J. 47 (2006); Brian Leiter, Top 25 Law Faculties in Scholarly Impact, 2005-2009, http:/www.leiterrankings.com/new/2010_scholarlyimpact.shtml

13 See Gregory Sisk, Valerie Aggerbeck, Debby Hackerson, and Mary Wells, Scholarly Impact of Law School Faculties in 2012: Applying Leiter Scores to Rank the Top Third, 9 U. ST. THom As L.J. 838 (2013), available at http://papers.ssrn.com/sol3/papers.cfm?abstract id=2109815 Gregory Sisk et al., Scholarly Impact of Law School Faculties: Extending the Leiter Rankings to the Top 70 (2010), available at: http $/ /$ papers.ssrn.com/sol3/papers.cfm?abstract $\mathrm{id}=1674764$

14 Theodore Eisenberg \& Martin T. Wells, Ranking and Explaining the Scholarly Impact of Law Schools, 27 J. L. STUD. 373 (1998); Theodore Eisenberg \& Martin T. Wells, Ranking Law Journals and the Limits of Journal Citation Reports, available at: http://papers.ssrn.com/sol3/papers.cfm?abstract id=2084169

15 See, e.g., Ronen Perry, The Relative Value of American Law Reviews: Refinement and Implementation, 39 ConN. L. REV. 1-41 (2006); Ronen Perry, The Relative Value of American Law Reviews: A Critical Appraisal of Ranking Methods, 11 VA J. L. \& TeCH. 1 (2006).

16 Fall 2014 1L Enrollment, available at: http:/www.americanbar.org/groups/legal_education/resources/statistics.html 
the ABA and posted to their website. ${ }^{17}$ I use the percentage of graduates from the class of 2014 who were employed ten months after graduation in full-time, permanent JD required jobs, excluding schoolfunded and solo practitioners. ${ }^{18}$ Finally, this paper uses citations to each school's primary law review from 2007 through 2014, which are provided by John Doyle of Washington and Lee's law library. ${ }^{19}$

The analysis here uses standardized scores for each of those three variables. The student input (median LSAT for class entering in fall 2014) and output (percentage of the class employed at full-time, JD-required jobs ten months after graduation, excluding solo practitioners and school-funded positions), the raw scores were transformed to standard scores with a mean of 50 and a standard deviation of 10. The data for law review citations were very skewed at the upper end; therefore, the raw scores were adjusted using a common log transformation and then were transformed to a standard score, with a mean of 50 and a standard deviation of 10 . Table 2 presents the raw data on those three

17 Complete Employment Data for 2014 is available at:

http://employmentsummary.abaquestionnaire.org/

The instructions regarding reporting employment status for the class of 2014 are in ABA Section of Legal Education and Admissions to the Bar, 2015 Employment Questionnaire (For 2014 Graduates) Definitions \& Instructions, available at: $\mathrm{http} / /$ www.americanbar.org/content/dam/aba/administrative/legal_education_and_admissions_to_the_b ar/Questionnaires/2015_employment_questionnaire_definitionsandinstructions.authcheckdam.pdf

${ }^{18} \mathrm{http}: / /$ employmentsummary.abaquestionnaire.org/

19 Law Journals: Submissions and Ranking, 2007 - 2014, released in March 2015, which is available at:

http://awlib.wlu.edu/LJ/index.aspx

For six schools -- Atlanta's John Marshall, Arizona Summit, Charlotte, Drexel, Elon, the University of California-Irvine -- whose law reviews were published for less than the full period under study, I assumed that their remaining years would generate the same number of citations per year that they had, on average, generated to this point. Northeastern University, which has no law review, was assigned a rank at the median of law reviews for the other 194 schools.

For Widener University this paper uses citations to the Delaware Journal of Corporate Law rather than the Widener Law Review. The former is older and more heavily cited than the latter and it seemed in this case fairer to Widener Law School to give the school credit for the journal's performance. See The Delaware Journal of Coporate Law, available at: http:/www.djcl.org/; History of Widener Law Review, available at http://widenerlawreview.org/about-wlr/ There appear to be no other school where a "speciality" law review is more heavily cited than the "main" law review. I have also combined data on LSAT and employment for the two Widener campuses in this study, so that there is only one ranking for Widener. Given the recent installation of separate deans for the Widener Delaware and Harrisburg campuses future studies - if any - will likely rank the two schools separately.

I assigned the median law review citations to Northeastern University, which does not publish a law review. 
variables; it also presents the standard scores and schools' ranks on the combined scores on (a) LSAT and employment, and (b) the combined scores on LSAT, employment, and law review citations.

I also analyze the 153 schools that were ranked by U.S. News in its March 2015 analysis. ${ }^{20}$ For those 153 schools this paper provides the difference between the new ranks on the two and three variable ranks and the U.S. News rank. Throughout this paper I refer to the U.S. News overall ranks as a benchmark to gauge the new rankings developed here. This is because U.S. News is the leading current method for ranking law schools and I want to see how the new rankings here compare to the benchmark that most people use. This is not meant as an endorsement of U.S. News; in fact, one of my hopes is that this paper will add to the growing interest in alternative measures.

Perhaps a competitor ranking scheme for U.S News should include other variables. In fact, I have previously suggested that other factors be added to the U.S. News ranking equation, including the percentage of African American students fsat each law school. ${ }^{21}$ I continue to believe that measures including the diversity of students and faculty - and other measures like faculty quality - are important. In future years I hope to include some more of those kinds of data in rankings. However, this particular exploration of a relatively simple ranking focuses on only three factors.

\section{LSAT and Employment: The Two-Variable Rankings}

One simple way of ranking employs student quality and employment outcomes. Table 3 provides standard scores for schools' median LSAT for the class entering in 2014 and the percentage of the class who graduated in 2014 who were employed at full-time, long-term JD-required jobs ten months after graduation, excluding school-funded and solo practitioner positions. The table lists schools ranked according to their performance on the two-variable standard score average. For the sake of comparison with U.S. News, the fifth column presents each school's U.S. News ranking for the 153 schools ranked by U.S. News. The sixth and final column subtracts the new rank from the U.S. News overall rank. That shows how much the new two-variable rank compares to the U.S. News rank.

The two-variable scores correlate highly with U.S. News' peer assessment scores (.92). And, examining the 153 ranked schools, there is also a high correlation between two-variable scores and U.S. News ranks (.90). Table 4 lists the schools that improved the most in the two- variable rank in comparison with their U.S. News rankings. Those are institutions whose entering students and employment outcomes suggest they are substantially better than their U.S. News rankings would suggest. For at least some of the largest outliers this seems to be due to their strong job performance. For instance, Drexel and the University of Montana each places 40 spots ahead of its U.S. News rank.

20 There were another 42 schools that were listed by U.S. News as unranked. While those schools are included in this paper, they are excluded from the analysis involving change from U.S. News rank to the new rank here.

${ }^{21}$ Alfred L. Brophy, African American Student Enrollment and Law School Ranking, 27 St. John's J. Civ. Rights \& Econ. Development 15 (2013). 
Graduates of both schools have better employment outcomes than their U.S. News rank would predict. Table 5, by contrast, lists the schools that declined the most in the two-variable in comparison with their U.S. News rankings. As with the schools that improved the most, employment rank seems to be the cause. These numbers suggest that prospective students should look very carefully at placement outcomes and that following the overall U.S. News rankings by themselves may lead students astray.

\section{LSAT, Employment, and Law Review Citations: The Three-Variable Ranking}

While some observers of law school rankings believe that the two key factors are LSAT and employment, there is good reason to add another measure to gauge reputation of an institution. U.S. News does this primarily through their reputation scores, which collectively account for $40 \%$ of their ranking. ${ }^{22}$ Because those numbers are proprietary, are notoriously static, and are perhaps subject to gaming by schools, I sought another variable that might provide a measure of law school reputation and quality. Citations to law schools' main law reviews are highly correlated with U.S. News' peer assessment scores, so they provide a free, close proxy. ${ }^{23}$ But there are also independent reasons to suggest that recent citations may provide a good measure: they reflect citations to work published recently and thus may represent the intellectual orientation of the best students at a school. Moreover, because the journals that are perceived as better will likely have a better selection of articles there is something of a feedback loop. Reviews that are perceived as best have the opportunity to publish what they believe to be the best work. There are reasons to be skeptical of these assumptions, of course. Not the least one of them is that we know that the journals associated with the most prestigious schools do not always publish the most-cited work. ${ }^{24}$ Nevertheless, I have chosen to use citations as a third variable to help bring some other precision related to prestige and intellectual culture of the schools to the ranking process. Citations offer a measure of the success of the law school's academic project.

Table 6 reports standard scores for 195 the number of citations to each school's main law review from 2007 through 2014 in addition to the standard scores for the two-variable ranks. It also reports the mean of those three ranks for each school and it orders the schools based on those three variables. Finally, it reports the school's U.S. News ranking in spring 2015 and the difference between the new rank and the U.S. News rank.

This paper uses standard scores for each of the three variables and then averages those scores

22 Flanigan and Morse, supra note 2.

23 See Alfred L. Brophy, The Relationship Between Law Review Citations and Law School Reputation, 39 ConN. L. REV. 43, 50 (2006); Brophy, supra note 8.

${ }^{24}$ See, e.g., Alfred L. Brophy, The Signaling Value of Law Reviews: An Exploration of Citations and Prestige, 36 Fla. StAte U. L. ReV. 229 (2009). 
to preserve as much data as possible. ${ }^{25}$ The use of standard scores allows for measuring finer distinctions about the differences between schools than ranks. The mean of the three variable average scores for all 195 schools is 50; the standard deviation is 9.25 . Harvard has the highest average standard score (72.5); Texas Tech is at the median, with an average standard score of 49.69; Charlotte School of Law is the lowest, with an average standard score of 28.68. Figure 1 displays the relationship between schools' average standard scores by plotting standard scores against schools' ranks. It is apparent that the most highly ranked schools have average scores substantially larger than almost all others; many schools in the middle are within a fairly narrow band of average standard scores, and average standard scores decline noticeably towards the bottom of the rank. One implication of this is that for mid-range schools, other factors, such as tuition, scholarships, location, and special aspects of the curriculum may be particularly important in school choice.

Figure 1. Ranks of Law Schools Plotted Against Average Standard Scores on Three-Variable Rank (LSAT, Employment, and Citations).

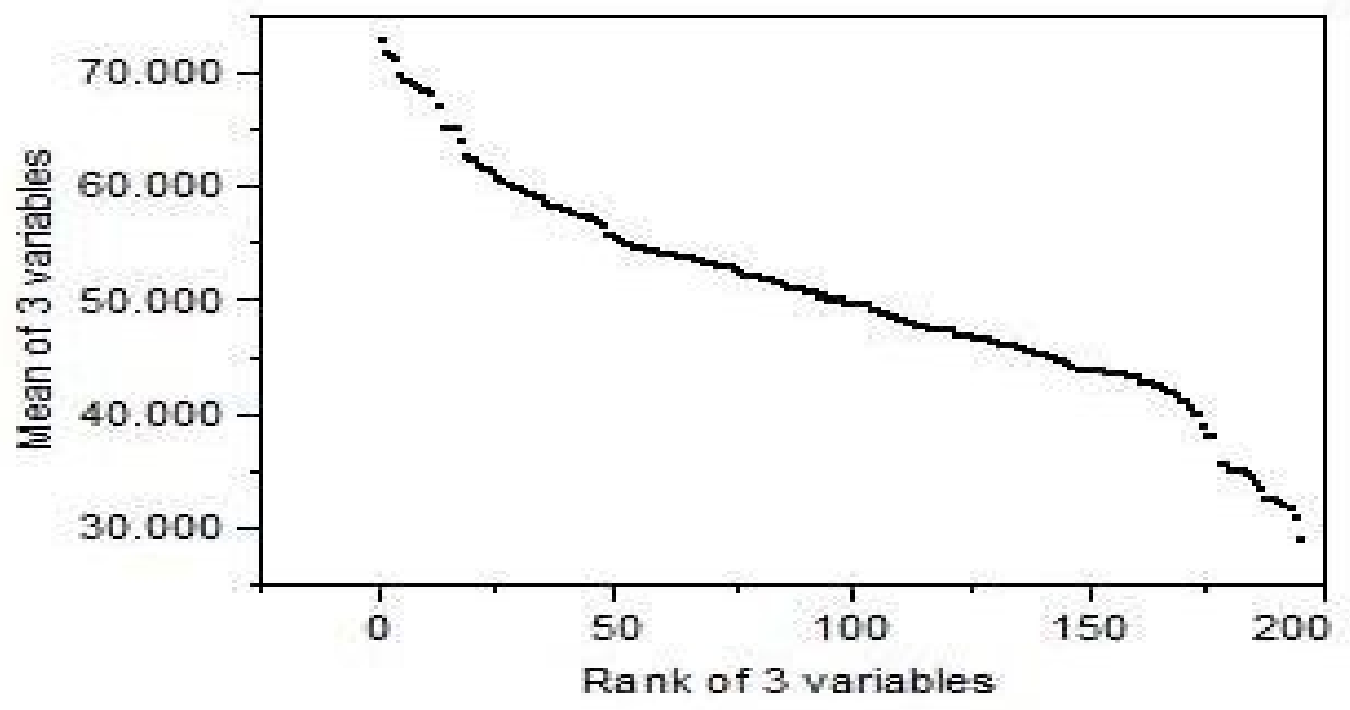

Some schools have a notable difference between their new ranking and the U.S. News ranking. Table 7 lists those schools whose new rank improves by at least twenty places in comparison to their U.S. News ranking. That is, the three-variable ranking suggests that the schools are substantially better than U.S. News suggests. Some schools that did particularly well in the previous version of this study

25 The last iteration of this paper used ranks on those three variables and averaged those ranks. See Alfred L. Brophy, Ranking Law Schools with LSATs, Employment Outcomes, and Law Review Citations, forthcoming 91 InDIANA LAw JOURNAL SUPPLEMENT (2015). 
have, unsurprisingly, found this ranking method superior to U.S. News' method. ${ }^{26}$ By contrast, table 8 lists the schools whose new rank is significantly worse in comparison to their U.S. News ranking. That is, the schools listed in table 8 perform less well on the new rank than on U.S. News. Those schools have relatively poorer job placement, LSAT medians, and/or law review citations than their U.S. News rank would predict.

The three-variable score and U.S. News peer assessments are highly correlated (.94). (Table 9) Focusing just on U.S. News' 153 ranked law schools, the correlation between U.S. News rank and the three-variable rank is -.91 . The upshot of this is that the three-variable ranks are quite close approximations of U.S. News. In some ways this is good news; the substitute rankings, which rely on readily available data, are confirmed by U.S. News.

\section{Conclusions}

There are several conclusions from this initial exploration. First, one can largely replicate the U.S. News rankings with a small number of easily available data. While U.S. News has received extraordinary attention, their rankings are quite similar to a simple compilation of a few key variables basic LSAT data, basic employment data, and basic citation data. However, and second, there are some schools that are rather significantly either under-ranked (or over-ranked) by U.S. News when we focus on several critical factors. That is, when we focus on student quality, employment outcome, and citations to a school's law review, some schools appear to be significantly better (and in some cases significantly worse) than their U.S. News ranking. Just as we are hearing about personalized medicine, we should try to match prospective students to schools that meet their needs. Prospective students should use general rankings measures like those of U.S. News and those presented here as a starting point. But they should also look at how well schools meet their needs for affordability, job outcomes, educational quality, their own family situation, and vocational goals. Prospective students should examine closely at those factors that matter to them, rather than just focusing on overall U.S. News ranking.

${ }^{26}$ See Chuck Crumbo, USC Law School Dean: \$80M Building a Launching Point, Columbia Regional Business Report (September 1, 2014) http:/www.columbiabusinessreport.com/news/52380-usc-law-school-dean-80m-building-a-launchingpoint (quoting University of South Carolina Law Dean Wilcox who noted that a previous version of this study, which ranked South Carolina Law 56, may be a better ranking method than U.S. News); Boyd School of Law Ranked 53 on Law Schools List Based on LSATs, Employment and Citations available at: http://unlvlawblog.blogspot.com/2014/06/boyd-school-of-law-ranked-53-on-law.html (nothing the UNLV's William S. Boyd School of law is ranked 53 in last year's version of this study). 
Table 1

Schools with Largest Percentage of School-funded, JD-Required, Full-time Long-term Positions

Percentage of Class of 2014

In School-Funded, Full-Time, Long-Term

School

JD-Required Positions

Emory $\quad 19.4$

USC 14.3

George Washington $\quad 13.4$

Notre Dame $\quad 12.3$

Vanderbilt $\quad 11.3$

UC-Davis $\quad 11.2$

UC-Irvine $\quad 10.8$

Georgetown $\quad 10.2$

American $\quad 9.6$

Virginia $\quad 9.5$

UCLA $\quad 9.2$

William \& Mary 8.8

Michigan $\quad 8.5$

Illinois $\quad 8.1$

BYU 8.0

NYU $\quad 7.5$

UC-Berkeley $\quad 7.0$

Columbia $\quad 6.6$

Texas $\quad 6.6$

Arizona $\quad 6.3$

Cornell $\quad 5.8$

Washington (St. Louis) $\quad 5.4$

Stanford $\quad 5.3$

Chicago $\quad 5.2$ 
Table 2

Law School Ranks with Combined Standard Scores of LSAT and Employment and LSAT, Employment, and Law Review Citations

\begin{tabular}{|c|c|c|}
\hline Rank & Rank & \\
\hline 2 var & 3 var & School \\
\hline 1 & 1 & Harvard \\
\hline 2 & 2 & Columbia \\
\hline 3 & 4 & Pennsylvania \\
\hline 4 & 3 & Stanford \\
\hline 5 & 8 & Chicago \\
\hline 6 & 5 & NYU \\
\hline 7 & 6 & Duke \\
\hline 8 & 9 & Cornell \\
\hline 9 & 7 & Virginia \\
\hline 10 & 12 & UC-Berkeley \\
\hline 11 & 11 & Michigan \\
\hline 12 & 10 & Yale \\
\hline 13 & 13 & Northwestern \\
\hline 14 & 17 & Vanderbilt \\
\hline 15 & 15 & Texas \\
\hline 16 & 16 & UCLA \\
\hline 17 & 21 & Washington (St. Louis) \\
\hline 18 & 14 & Georgetown \\
\hline 19 & 18 & Minnesota \\
\hline 20 & 22 & Boston College \\
\hline 21 & 26 & USC \\
\hline 22 & 19 & Iow a \\
\hline 23 & 33 & Georgia \\
\hline 24 & 25 & George Washington \\
\hline 25 & 31 & Alabama \\
\hline 26 & 23 & Boston University \\
\hline 27 & 20 & Fordham \\
\hline 28 & 29 & Emory \\
\hline 29 & 24 & Notre Dame \\
\hline 30 & 44 & Arizona State \\
\hline 31 & 37 & BYU \\
\hline 32 & 28 & North Carolina \\
\hline 33 & 60 & UC-Irvine \\
\hline 34 & 30 & UC-Davis \\
\hline 35 & 36 & Ohio State \\
\hline 36 & 27 & William \& Mary \\
\hline
\end{tabular}

\begin{tabular}{|c|c|c|c|c|c|}
\hline \multicolumn{3}{|c|}{ Standard scores } & \multicolumn{3}{|c|}{ Raw scores } \\
\hline LSAT & Emp $\%$ & Cites & LSAT & Emp \% & Cites \\
\hline 75.93 & 70.55 & 71.03 & 173 & 85.49 & 6506 \\
\hline 74.45 & 71.73 & 68.29 & 172 & 87.18 & 4900 \\
\hline 70.00 & 74.67 & 68.19 & 169 & 91.37 & 4849 \\
\hline 74.45 & 70.22 & 68.76 & 172 & 85.03 & 5148 \\
\hline 71.48 & 71.37 & 63.28 & 170 & 86.67 & 2917 \\
\hline 71.48 & 70.91 & 65.56 & 170 & 86.01 & 3696 \\
\hline 70.00 & 72.24 & 64.70 & 169 & 87.91 & 3380 \\
\hline 67.04 & 73.75 & 64.54 & 167 & 90.05 & 3325 \\
\hline 70.00 & 70.07 & 66.69 & 169 & 84.81 & 4155 \\
\hline 67.04 & 70.21 & 66.01 & 167 & 85.02 & 3870 \\
\hline 68.52 & 67.95 & 67.40 & 168 & 81.79 & 4472 \\
\hline 75.93 & 59.37 & 69.12 & 173 & 69.57 & 5344 \\
\hline 68.52 & 65.29 & 66.52 & 168 & 78.01 & 4080 \\
\hline 67.04 & 62.64 & 64.08 & 167 & 74.23 & 3170 \\
\hline 67.04 & 60.53 & 66.62 & 167 & 71.23 & 4123 \\
\hline 67.04 & 60.47 & 66.57 & 167 & 71.13 & 4101 \\
\hline 65.56 & 61.69 & 58.35 & 166 & 72.87 & 1752 \\
\hline 67.04 & 59.31 & 67.97 & 167 & 69.49 & 4743 \\
\hline 62.60 & 61.76 & 66.32 & 164 & 72.97 & 3996 \\
\hline 59.63 & 62.73 & 62.14 & 162 & 74.36 & 2593 \\
\hline 65.56 & 56.15 & 59.28 & 166 & 64.98 & 1928 \\
\hline 56.67 & 64.78 & 65.03 & 160 & 77.27 & 3496 \\
\hline 61.11 & 60.12 & 55.15 & 163 & 70.64 & 1258 \\
\hline 64.08 & 56.45 & 61.90 & 165 & 65.41 & 2530 \\
\hline 61.11 & 59.38 & 57.36 & 163 & 69.59 & 1581 \\
\hline 61.11 & 58.19 & 63.87 & 163 & 67.89 & 3102 \\
\hline 61.11 & 58.10 & 66.62 & 163 & 67.76 & 4124 \\
\hline 64.08 & 54.80 & 59.49 & 165 & 63.06 & 1971 \\
\hline 61.11 & 57.20 & 64.75 & 163 & 66.48 & 3399 \\
\hline 59.63 & 58.04 & 53.20 & 162 & 67.68 & 1028 \\
\hline 59.63 & 57.84 & 55.95 & 162 & 67.39 & 1366 \\
\hline 58.15 & 58.78 & 62.06 & 161 & 68.72 & 2571 \\
\hline 62.60 & 54.31 & 43.74 & 164 & 62.37 & 386 \\
\hline 59.63 & 57.06 & 61.31 & 162 & 66.27 & 2381 \\
\hline 55.19 & 61.01 & 57.58 & 159 & 71.90 & 1617 \\
\hline 61.11 & 54.94 & 64.00 & 163 & 63.26 & 3145 \\
\hline
\end{tabular}




\begin{tabular}{|c|c|c|c|c|c|c|c|c|}
\hline 37 & 35 & Washington (Seattle) & 62.60 & 53.36 & 59.58 & 164 & 61.00 & 1989 \\
\hline 38 & 50 & Kentucky & 49.26 & 66.58 & 48.85 & 155 & 79.84 & 655 \\
\hline 39 & 45 & SMU & 58.15 & 57.52 & 53.96 & 161 & 66.93 & 1112 \\
\hline 40 & 39 & Wake Forest & 58.15 & 57.46 & 57.49 & 161 & 66.84 & 1603 \\
\hline 41 & 43 & Colorado & 58.15 & 57.33 & 55.64 & 161 & 66.67 & 1324 \\
\hline 42 & 38 & Arizona & 58.15 & 56.36 & 58.73 & 161 & 65.28 & 1822 \\
\hline 43 & 32 & Illinois & 58.15 & 55.69 & 62.99 & 161 & 64.32 & 2831 \\
\hline 44 & 41 & Washington \& Lee & 58.15 & 55.31 & 59.05 & 161 & 63.78 & 1884 \\
\hline 45 & 42 & Wisconsin & 58.15 & 55.15 & 58.17 & 161 & 63.56 & 1720 \\
\hline 46 & 34 & Indiana (Bloomington) & 58.15 & 55.12 & 62.32 & 161 & 63.51 & 2642 \\
\hline 47 & 74 & Baylor & 55.19 & 57.50 & 44.62 & 159 & 66.91 & 423 \\
\hline 48 & 58 & Georgia State & 53.71 & 58.75 & 49.05 & 158 & 68.69 & 669 \\
\hline 49 & 40 & Florida & 53.71 & 58.47 & 60.56 & 158 & 68.28 & 2203 \\
\hline 50 & 48 & Florida State & 55.19 & 56.90 & 53.72 & 159 & 66.04 & 1085 \\
\hline 51 & 83 & New Mexico & 46.30 & 65.55 & 41.93 & 153 & 78.38 & 320 \\
\hline 52 & 51 & Seton Hall & 50.74 & 60.78 & 52.68 & 156 & 71.58 & 974 \\
\hline 53 & 47 & Tulane & 58.15 & 53.01 & 57.18 & 161 & 60.50 & 1552 \\
\hline 54 & 56 & Kansas & 53.71 & 56.55 & 52.20 & 158 & 65.55 & 927 \\
\hline 55 & 53 & Penn State & 53.71 & 56.00 & 53.30 & 158 & 64.77 & 1039 \\
\hline 56 & 54 & Miami & 52.23 & 57.39 & 53.15 & 157 & 66.75 & 1023 \\
\hline 57 & 79 & Oklahoma & 52.23 & 57.17 & 45.30 & 157 & 66.43 & 454 \\
\hline 58 & 62 & Temple & 56.67 & 52.71 & 51.05 & 160 & 60.08 & 823 \\
\hline 59 & 59 & UNLV & 53.71 & 55.48 & 51.93 & 158 & 64.03 & 901 \\
\hline 60 & 49 & Houston & 55.19 & 53.86 & 56.50 & 159 & 61.72 & 1447 \\
\hline 61 & 68 & Villanova & 52.23 & 56.16 & 50.89 & 157 & 65.00 & 809 \\
\hline 62 & 52 & Utah & 53.71 & 54.48 & 55.19 & 158 & 62.60 & 1263 \\
\hline 63 & 69 & Nebraska & 50.74 & 57.33 & 50.26 & 156 & 66.67 & 758 \\
\hline 64 & 55 & Missouri (Columbia) & 52.23 & 55.77 & 54.71 & 157 & 64.44 & 1202 \\
\hline 65 & 71 & LSU & 49.26 & 58.56 & 50.23 & 155 & 68.42 & 756 \\
\hline 66 & 66 & Richmond & 56.67 & 49.64 & 53.73 & 160 & 55.70 & 1086 \\
\hline 67 & 65 & Loyola (Los Angeles) & 55.19 & 50.95 & 53.95 & 159 & 57.58 & 1111 \\
\hline 68 & 64 & Maryland & 55.19 & 50.61 & 54.30 & 159 & 57.09 & 1152 \\
\hline 69 & 77 & St. John's & 52.23 & 53.15 & 49.64 & 157 & 60.70 & 711 \\
\hline 70 & 70 & South Carolina & 49.26 & 56.06 & 52.93 & 155 & 64.85 & 1000 \\
\hline 71 & 57 & George Mason & 58.15 & 47.16 & 56.44 & 161 & 52.17 & 1437 \\
\hline 72 & 46 & Cardozo & 55.19 & 49.93 & 63.80 & 159 & 56.12 & 3081 \\
\hline 73 & 110 & Montana & 47.78 & 57.04 & 39.23 & 154 & 66.25 & 242 \\
\hline 74 & 76 & Rutgers (New ark) & 50.74 & 53.83 & 50.96 & 156 & 61.67 & 815 \\
\hline 75 & 87 & Tulsa & 47.78 & 56.38 & 47.49 & 154 & 65.31 & 569 \\
\hline 76 & 82 & Northeastern & 58.15 & 45.96 & 50.24 & 161 & 50.46 & 757 \\
\hline 77 & 119 & New Hampshire & 49.26 & 54.55 & 37.72 & 155 & 62.70 & 207 \\
\hline 78 & 75 & Case Western & 55.19 & 48.56 & 52.51 & 159 & 54.17 & 957 \\
\hline 79 & 78 & Tennessee & 53.71 & 49.12 & 52.18 & 158 & 54.97 & 925 \\
\hline 80 & 73 & St. Louis & 49.26 & 53.39 & 54.89 & 155 & 61.05 & 1224 \\
\hline 81 & 89 & Mercer & 44.82 & 57.66 & 48.80 & 152 & 67.13 & 652 \\
\hline 82 & 132 & Florida International & 50.74 & 51.56 & 35.53 & 156 & 58.44 & 165 \\
\hline
\end{tabular}




\begin{tabular}{|c|c|c|}
\hline 83 & 102 & Rutgers (Camden) \\
\hline 84 & 72 & Cincinnati \\
\hline 85 & 94 & Louisville \\
\hline 86 & 85 & Loyola (Chicago) \\
\hline 87 & 113 & Drexel \\
\hline 88 & 67 & Lew is \& Clark \\
\hline 89 & 80 & SUNY (Buffalo) \\
\hline 90 & 100 & Syracuse \\
\hline 91 & 81 & Pepperdine \\
\hline 92 & 96 & Drake \\
\hline 93 & 86 & Denver \\
\hline 94 & 61 & UC-Hastings \\
\hline 95 & 138 & Haw aii \\
\hline 96 & 98 & Texas Tech \\
\hline 97 & 63 & Connecticut \\
\hline 98 & 114 & Idaho \\
\hline 99 & 103 & West Virginia \\
\hline 100 & 90 & San Diego \\
\hline 101 & 99 & Washburn \\
\hline 102 & 106 & Pittsburgh \\
\hline 103 & 84 & Brooklyn \\
\hline 104 & 117 & Stetson \\
\hline 105 & 88 & Chicago-Kent \\
\hline 106 & 108 & Creighton \\
\hline 107 & 101 & Missouri (Kansas City) \\
\hline 108 & 93 & Albany \\
\hline 109 & 97 & Indiana (Indianapolis) \\
\hline 110 & 115 & Wayne State \\
\hline 111 & 128 & South Dakota \\
\hline 112 & 130 & Campbell \\
\hline 113 & 109 & Mis sis sippi \\
\hline 114 & 121 & Arkansas (Fayetteville) \\
\hline 115 & 95 & Hofstra \\
\hline 116 & 122 & Willamette \\
\hline 117 & 127 & Duquesne \\
\hline 118 & 104 & Oregon \\
\hline 119 & 91 & DePaul \\
\hline 120 & 131 & Chapman \\
\hline 121 & 129 & Gonzaga \\
\hline 122 & 124 & Memphis \\
\hline 123 & 105 & William Mitchell \\
\hline 124 & 92 & American \\
\hline 125 & 152 & Northern Illinois \\
\hline 126 & 134 & South Texas \\
\hline 127 & 139 & North Dakota \\
\hline 128 & 118 & Catholic \\
\hline
\end{tabular}

\begin{tabular}{|c|c|c|c|c|c|}
\hline 49.26 & 52.99 & 46.14 & 155 & 60.47 & 495 \\
\hline 49.26 & 52.65 & 55.76 & 155 & 60.00 & 1340 \\
\hline 46.30 & 55.03 & 48.92 & 153 & 63.39 & 660 \\
\hline 52.23 & 48.85 & 51.89 & 157 & 54.58 & 898 \\
\hline 47.78 & 52.85 & 42.54 & 154 & 60.28 & 341 \\
\hline 53.71 & 46.83 & 58.75 & 158 & 51.71 & 1825 \\
\hline 47.78 & 52.43 & 54.47 & 154 & 59.69 & 1172 \\
\hline 49.26 & 50.79 & 48.61 & 155 & 57.35 & 639 \\
\hline 56.67 & 43.15 & 54.65 & 160 & 46.46 & 1195 \\
\hline 44.82 & 54.81 & 49.68 & 152 & 63.08 & 714 \\
\hline 50.74 & 48.80 & 53.27 & 156 & 54.51 & 1035 \\
\hline 53.71 & 45.81 & 60.94 & 158 & 50.25 & 2291 \\
\hline 50.74 & 48.70 & 36.63 & 156 & 54.37 & 185 \\
\hline 47.78 & 51.40 & 49.89 & 154 & 58.22 & 730 \\
\hline 52.23 & 46.95 & 61.02 & 157 & 51.87 & 2310 \\
\hline 43.34 & 55.62 & 43.74 & 151 & 64.23 & 386 \\
\hline 47.78 & 50.80 & 49.69 & 154 & 57.36 & 715 \\
\hline 55.19 & 43.28 & 52.47 & 159 & 46.64 & 953 \\
\hline 43.34 & 55.03 & 50.31 & 151 & 63.39 & 762 \\
\hline 52.23 & 46.11 & 47.54 & 157 & 50.68 & 572 \\
\hline 50.74 & 47.29 & 54.96 & 156 & 52.36 & 1234 \\
\hline 49.26 & 48.72 & 43.89 & 155 & 54.40 & 392 \\
\hline 52.23 & 45.64 & 53.47 & 157 & 50.00 & 1057 \\
\hline 44.82 & 52.76 & 47.57 & 152 & 60.15 & 574 \\
\hline 44.82 & 52.75 & 50.97 & 152 & 60.14 & 816 \\
\hline 43.34 & 53.89 & 53.12 & 151 & 61.76 & 1020 \\
\hline 44.82 & 51.80 & 52.48 & 152 & 58.78 & 954 \\
\hline 50.74 & 45.84 & 45.96 & 156 & 50.30 & 486 \\
\hline 38.89 & 57.33 & 42.98 & 148 & 66.67 & 357 \\
\hline 44.82 & 51.10 & 42.82 & 152 & 57.79 & 351 \\
\hline 49.26 & 46.22 & 49.12 & 155 & 50.84 & 674 \\
\hline 47.78 & 47.54 & 45.98 & 154 & 52.71 & 487 \\
\hline 44.82 & 49.95 & 54.60 & 152 & 56.15 & 1188 \\
\hline 43.34 & 51.39 & 45.66 & 151 & 58.20 & 471 \\
\hline 44.82 & 49.76 & 44.73 & 152 & 55.88 & 428 \\
\hline 52.23 & 42.20 & 51.99 & 157 & 45.11 & 907 \\
\hline 46.30 & 48.09 & 56.18 & 153 & 53.50 & 1399 \\
\hline 50.74 & 43.60 & 43.79 & 156 & 47.10 & 388 \\
\hline 46.30 & 47.80 & 44.91 & 153 & 53.09 & 436 \\
\hline 46.30 & 47.51 & 46.20 & 153 & 52.67 & 498 \\
\hline 44.82 & 48.32 & 53.28 & 152 & 53.82 & 1036 \\
\hline 50.74 & 42.13 & 57.66 & 156 & 45.00 & 1631 \\
\hline 41.86 & 50.95 & 38.04 & 150 & 57.58 & 214 \\
\hline 43.34 & 49.41 & 44.51 & 151 & 55.38 & 418 \\
\hline 41.86 & 50.25 & 43.25 & 150 & 56.58 & 367 \\
\hline 49.26 & 42.69 & 49.77 & 155 & 45.81 & 721 \\
\hline
\end{tabular}




\begin{tabular}{|c|c|c|}
\hline 129 & 120 & Pace \\
\hline 130 & 137 & St. Thomas (Minneapolis) \\
\hline 131 & 151 & Samford \\
\hline 132 & 157 & CUNY \\
\hline 133 & 145 & Wyoming \\
\hline 134 & 147 & Nova Southeastern \\
\hline 135 & 123 & How ard \\
\hline 136 & 143 & Baltimore \\
\hline 137 & 111 & Akron \\
\hline 138 & 107 & Michigan State \\
\hline 139 & 141 & Southern Illinois \\
\hline 140 & 150 & Texas A\&M \\
\hline 141 & 144 & Loyola (New Orleans) \\
\hline 142 & 158 & Oklahoma City \\
\hline 143 & 153 & Arkansas (Little Rock) \\
\hline 144 & 116 & Marquette \\
\hline 145 & 112 & Seattle \\
\hline 146 & 133 & Cleveland State \\
\hline 147 & 125 & Vermont \\
\hline 148 & 142 & Maine \\
\hline 149 & 135 & John Marshall (Chicago) \\
\hline 150 & 154 & St. Mary's \\
\hline 151 & 126 & Santa Clara \\
\hline 152 & 159 & Regent \\
\hline 153 & 149 & Quinnipiac \\
\hline 154 & 161 & Hamline \\
\hline 155 & 160 & Touro \\
\hline 156 & 136 & New York Law School \\
\hline 157 & 169 & Dayton \\
\hline 158 & 163 & Charleston \\
\hline 159 & 166 & California Western \\
\hline 160 & 148 & Ohio Northern \\
\hline 161 & 140 & Widener (both campuses) \\
\hline 162 & 146 & McGeorge \\
\hline 163 & 176 & Liberty \\
\hline 164 & 168 & Northern Kentucky \\
\hline 165 & 174 & Miss is sippi College \\
\hline 166 & 171 & St. Thomas (Miami ) \\
\hline 167 & 170 & Roger Williams \\
\hline 168 & 156 & Toledo \\
\hline 169 & 165 & New England \\
\hline 170 & 172 & Detroit \\
\hline 171 & 155 & San Francisco \\
\hline 172 & 162 & Suffolk \\
\hline 173 & 164 & Southw estern \\
\hline 174 & 167 & Valparaiso \\
\hline
\end{tabular}

\begin{tabular}{|c|c|c|c|c|c|}
\hline 43.34 & 48.38 & 49.64 & 151 & 53.92 & 711 \\
\hline 47.78 & 43.92 & 44.41 & 154 & 47.55 & 414 \\
\hline 43.34 & 48.22 & 39.31 & 151 & 53.68 & 244 \\
\hline 47.78 & 43.76 & 38.31 & 154 & 47.33 & 220 \\
\hline 46.30 & 45.14 & 41.59 & 153 & 49.30 & 309 \\
\hline 38.89 & 52.40 & 39.96 & 148 & 59.64 & 261 \\
\hline 43.34 & 47.81 & 48.93 & 151 & 53.10 & 661 \\
\hline 44.82 & 46.08 & 42.93 & 152 & 50.64 & 355 \\
\hline 46.30 & 44.52 & 52.98 & 153 & 48.41 & 1005 \\
\hline 49.26 & 41.50 & 54.75 & 155 & 44.11 & 1207 \\
\hline 37.41 & 53.32 & 44.15 & 147 & 60.95 & 403 \\
\hline 47.78 & 42.91 & 40.18 & 154 & 46.12 & 267 \\
\hline 46.30 & 44.03 & 43.28 & 153 & 47.71 & 368 \\
\hline 38.89 & 51.27 & 39.58 & 148 & 58.02 & 251 \\
\hline 41.86 & 48.16 & 40.70 & 150 & 53.60 & 282 \\
\hline 44.82 & 44.98 & 52.42 & 152 & 49.07 & 948 \\
\hline 47.78 & 41.95 & 53.99 & 154 & 44.75 & 1115 \\
\hline 46.30 & 43.08 & 47.89 & 153 & 46.36 & 593 \\
\hline 44.82 & 44.56 & 50.42 & 152 & 48.46 & 771 \\
\hline 46.30 & 43.05 & 45.15 & 153 & 46.32 & 447 \\
\hline 40.38 & 48.90 & 47.77 & 149 & 54.65 & 586 \\
\hline 41.86 & 45.96 & 42.57 & 150 & 50.46 & 342 \\
\hline 52.23 & 35.28 & 52.08 & 157 & 35.25 & 915 \\
\hline 44.82 & 42.18 & 42.25 & 152 & 45.08 & 331 \\
\hline 46.30 & 39.73 & 45.15 & 153 & 41.59 & 447 \\
\hline 43.34 & 42.58 & 42.87 & 151 & 45.64 & 353 \\
\hline 35.93 & 49.22 & 43.91 & 146 & 55.10 & 393 \\
\hline 43.34 & 40.82 & 52.13 & 151 & 43.13 & 920 \\
\hline 38.89 & 45.13 & 40.21 & 148 & 49.29 & 268 \\
\hline 38.89 & 45.11 & 43.43 & 148 & 49.25 & 374 \\
\hline 41.86 & 41.95 & 42.25 & 150 & 44.75 & 331 \\
\hline 41.86 & 41.90 & 47.49 & 150 & 44.68 & 569 \\
\hline 40.38 & 43.32 & 51.23 & 149 & 46.70 & 838 \\
\hline 43.34 & 40.19 & 48.92 & 151 & 42.25 & 660 \\
\hline 43.34 & 39.17 & 30.97 & 151 & 40.79 & 103 \\
\hline 41.86 & 40.24 & 42.60 & 150 & 42.31 & 343 \\
\hline 37.41 & 43.83 & 37.72 & 147 & 47.43 & 207 \\
\hline 38.89 & 41.41 & 41.80 & 148 & 43.98 & 316 \\
\hline 38.89 & 41.38 & 42.08 & 148 & 43.93 & 325 \\
\hline 43.34 & 36.79 & 49.80 & 151 & 37.40 & 723 \\
\hline 41.86 & 37.77 & 46.96 & 150 & 38.80 & 539 \\
\hline 44.82 & 34.70 & 41.46 & 152 & 34.43 & 305 \\
\hline 46.30 & 32.99 & 50.81 & 153 & 31.98 & 803 \\
\hline 35.93 & 42.86 & 48.98 & 146 & 46.04 & 664 \\
\hline 43.34 & 35.43 & 48.11 & 151 & 35.46 & 607 \\
\hline 34.45 & 41.96 & 48.92 & 145 & 44.77 & 660 \\
\hline
\end{tabular}




$\begin{array}{lll}175 & 187 & \text { Elon } \\ 176 & 182 & \text { John Marshall (Atlanta) } \\ 177 & 177 & \text { Barry } \\ 178 & 173 & \text { Capital } \\ 179 & 175 & \text { Western New England } \\ 180 & 192 & \text { Faulkner } \\ 181 & 181 & \text { Western State } \\ 182 & 184 & \text { North Carolina Central } \\ 183 & 180 & \text { Arizona Summit } \\ 184 & 194 & \text { Florida A\&M } \\ 185 & 178 & \text { Golden Gate } \\ 186 & 190 & \text { District of Columbia } \\ 187 & 188 & \text { Appalachian } \\ 188 & 179 & \text { Ave Maria } \\ 189 & 185 & \text { Florida Coastal } \\ 190 & 183 & \text { Whittier } \\ 191 & 193 & \text { Texas Southern } \\ 192 & 186 & \text { Thomas Jefferson } \\ 193 & 191 & \text { WMU Thomas M. Cooley } \\ 194 & 189 & \text { Southern Univ Law Center } \\ 195 & 195 & \text { Charlotte }\end{array}$

$\begin{array}{llllll}38.89 & 36.86 & 23.39 & 148 & 37.50 & 47 \\ 38.89 & 36.40 & 28.53 & 148 & 36.84 & 80 \\ 35.93 & 38.75 & 38.52 & 146 & 40.19 & 225 \\ 38.89 & 35.11 & 45.56 & 148 & 35.00 & 466 \\ 35.93 & 36.32 & 43.81 & 146 & 36.73 & 389 \\ 34.45 & 36.76 & 24.18 & 145 & 37.35 & 51 \\ 40.38 & 30.19 & 33.44 & 149 & 28.00 & 133 \\ 32.97 & 36.74 & 33.59 & 144 & 37.32 & 135 \\ 32.97 & 36.38 & 34.73 & 144 & 36.81 & 152 \\ 35.93 & 33.13 & 22.53 & 146 & 32.18 & 43 \\ 40.38 & 27.42 & 38.22 & 149 & 24.04 & 218 \\ 38.89 & 27.58 & 30.29 & 148 & 24.27 & 96 \\ 32.97 & 33.44 & 30.59 & 144 & 32.63 & 99 \\ 31.49 & 34.79 & 39.19 & 143 & 34.55 & 241 \\ 31.49 & 33.89 & 37.19 & 143 & 33.26 & 196 \\ 35.93 & 28.63 & 39.23 & 146 & 25.77 & 242 \\ 34.45 & 29.29 & 30.19 & 145 & 26.70 & 95 \\ 34.45 & 28.99 & 37.53 & 145 & 26.28 & 203 \\ 34.45 & 28.75 & 33.00 & 145 & 25.95 & 127 \\ 32.97 & 29.68 & 34.21 & 144 & 27.27 & 144 \\ 30.01 & 30.77 & 25.26 & 142 & 28.81 & 57\end{array}$


Table 3

Law Schools Rank on Two Variables:

\section{LSAT Median and Employment Rankings Compared to U.S. News 2016 Rankings}

Rank based on 2 variables (LSAT and employment), with standard scores for LSAT and employment, plus U.S. News rank and difference between new rank and U.S. News rank

\begin{tabular}{|c|c|c|c|c|c|}
\hline \multicolumn{2}{|l|}{ Rank } & \multicolumn{2}{|c|}{ Standard score } & \multirow{2}{*}{$\begin{array}{l}\text { USN } \\
\text { Rank }\end{array}$} & \multirow{2}{*}{$\begin{array}{l}\text { Difference between } \\
\text { USN rank \& New Rank }\end{array}$} \\
\hline ( 2 var) & School & LSAT & Employment & & \\
\hline 1 & Harvard & 75.93 & 70.55 & 2 & 1 \\
\hline 2 & Columbia & 74.45 & 71.73 & 4 & 2 \\
\hline 3 & Pennsylvania & 70.00 & 74.67 & 7 & 4 \\
\hline 4 & Stanford & 74.45 & 70.22 & 2 & -2 \\
\hline 5 & Chicago & 71.48 & 71.37 & 4 & -1 \\
\hline 6 & NYU & 71.48 & 70.91 & 6 & 0 \\
\hline 7 & Duke & 70.00 & 72.24 & 8 & 1 \\
\hline 8 & Cornell & 67.04 & 73.75 & 13 & 5 \\
\hline 9 & Virginia & 70.00 & 70.07 & 8 & -1 \\
\hline 10 & UC-Berkeley & 67.04 & 70.21 & 8 & -2 \\
\hline 11 & Michigan & 68.52 & 67.95 & 11 & 0 \\
\hline 12 & Yale & 75.93 & 59.37 & 1 & -11 \\
\hline 13 & Northw estern & 68.52 & 65.29 & 12 & -1 \\
\hline 14 & Vanderbilt & 67.04 & 62.64 & 17 & 3 \\
\hline 15 & Texas & 67.04 & 60.53 & 15 & 0 \\
\hline 16 & UCLA & 67.04 & 60.47 & 16 & 0 \\
\hline 17 & Washington (St. Louis) & 65.56 & 61.69 & 18 & 1 \\
\hline 18 & Georgetown & 67.04 & 59.31 & 14 & -4 \\
\hline 19 & Minnesota & 62.60 & 61.76 & 20 & 1 \\
\hline 20 & Boston College & 59.63 & 62.73 & 34 & 14 \\
\hline 21 & USC & 65.56 & 56.15 & 20 & -1 \\
\hline 22 & Iowa & 56.67 & 64.78 & 22 & 0 \\
\hline 23 & Georgia & 61.11 & 60.12 & 31 & 8 \\
\hline 24 & George Washington & 64.08 & 56.45 & 22 & -2 \\
\hline 25 & Alabama & 61.11 & 59.38 & 22 & -3 \\
\hline 26 & Boston University & 61.11 & 58.19 & 26 & 0 \\
\hline 27 & Fordham & 61.11 & 58.10 & 34 & 7 \\
\hline 28 & Emory & 64.08 & 54.80 & 19 & -9 \\
\hline 29 & Notre Dame & 61.11 & 57.20 & 22 & -7 \\
\hline 30 & Arizona State & 59.63 & 58.04 & 26 & -4 \\
\hline 31 & BYU & 59.63 & 57.84 & 34 & 3 \\
\hline 32 & North Carolina & 58.15 & 58.78 & 34 & 2 \\
\hline 33 & UC-Irvine & 62.60 & 54.31 & 30 & -3 \\
\hline 34 & UC-Davis & 59.63 & 57.06 & 31 & -3 \\
\hline 35 & Ohio State & 55.19 & 61.01 & 34 & -1 \\
\hline
\end{tabular}




\begin{tabular}{|c|c|}
\hline 36 & William \& Mary \\
\hline 37 & Washington (Seattle) \\
\hline 38 & Kentucky \\
\hline 39 & SMU \\
\hline 40 & Wake Forest \\
\hline 41 & Colorado \\
\hline 42 & Arizona \\
\hline 43 & Illinois \\
\hline 44 & Washington \& Lee \\
\hline 45 & Wisconsin \\
\hline 46 & Indiana (Bloomington) \\
\hline 47 & Baylor \\
\hline 48 & Georgia State \\
\hline 49 & Florida \\
\hline 50 & Florida State \\
\hline 51 & New Mexico \\
\hline 52 & Seton Hall \\
\hline 53 & Tulane \\
\hline 54 & Kansas \\
\hline 55 & Penn State \\
\hline 56 & Miami \\
\hline 57 & Oklahoma \\
\hline 58 & Temple \\
\hline 59 & UNLV \\
\hline 60 & Houston \\
\hline 61 & Villanova \\
\hline 62 & Utah \\
\hline 63 & Nebraska \\
\hline 64 & Missouri (Columbia) \\
\hline 65 & LSU \\
\hline 66 & Richmond \\
\hline 67 & Loyola (Los Angeles) \\
\hline 68 & Maryland \\
\hline 69 & St. John's \\
\hline 70 & South Carolina \\
\hline 71 & George Mason \\
\hline 72 & Cardozo \\
\hline 73 & Montana \\
\hline 74 & Rutgers (New ark) \\
\hline 75 & Tulsa \\
\hline 76 & Northeastern \\
\hline 77 & New Hampshire \\
\hline 78 & Case Western \\
\hline 79 & Tennessee \\
\hline 80 & St. Louis \\
\hline 81 & Mercer \\
\hline
\end{tabular}

\begin{tabular}{|c|c|c|c|}
\hline 61.11 & 54.94 & 29 & -7 \\
\hline 62.60 & 53.36 & 28 & -9 \\
\hline 49.26 & 66.58 & 63 & 25 \\
\hline 58.15 & 57.52 & 46 & 7 \\
\hline 58.15 & 57.46 & 47 & 7 \\
\hline 58.15 & 57.33 & 40 & -1 \\
\hline 58.15 & 56.36 & 42 & 0 \\
\hline 58.15 & 55.69 & 41 & -2 \\
\hline 58.15 & 55.31 & 42 & -2 \\
\hline 58.15 & 55.15 & 31 & -14 \\
\hline 58.15 & 55.12 & 34 & -12 \\
\hline 55.19 & 57.50 & 56 & 9 \\
\hline 53.71 & 58.75 & 56 & 8 \\
\hline 53.71 & 58.47 & 47 & -2 \\
\hline 55.19 & 56.90 & 50 & 0 \\
\hline 46.30 & 65.55 & 71 & 20 \\
\hline 50.74 & 60.78 & 63 & 11 \\
\hline 58.15 & 53.01 & 50 & -3 \\
\hline 53.71 & 56.55 & 67 & 13 \\
\hline 53.71 & 56.00 & 71 & 16 \\
\hline 52.23 & 57.39 & 63 & 7 \\
\hline 52.23 & 57.17 & 67 & 10 \\
\hline 56.67 & 52.71 & 52 & -6 \\
\hline 53.71 & 55.48 & 67 & 8 \\
\hline 55.19 & 53.86 & 59 & -1 \\
\hline 52.23 & 56.16 & 87 & 26 \\
\hline 53.71 & 54.48 & 42 & -20 \\
\hline 50.74 & 57.33 & 56 & -7 \\
\hline 52.23 & 55.77 & 59 & -5 \\
\hline 49.26 & 58.56 & 94 & 29 \\
\hline 56.67 & 49.64 & 52 & -14 \\
\hline 55.19 & 50.95 & 75 & 8 \\
\hline 55.19 & 50.61 & 47 & -21 \\
\hline 52.23 & 53.15 & 82 & 13 \\
\hline 49.26 & 56.06 & 94 & 24 \\
\hline 58.15 & 47.16 & 42 & -29 \\
\hline 55.19 & 49.93 & 75 & 3 \\
\hline 47.78 & 57.04 & 113 & 40 \\
\hline 50.74 & 53.83 & 87 & 13 \\
\hline 47.78 & 56.38 & 82 & 7 \\
\hline 58.15 & 45.96 & 87 & 11 \\
\hline 49.26 & 54.55 & 87 & 10 \\
\hline 55.19 & 48.56 & 59 & -19 \\
\hline 53.71 & 49.12 & 52 & -27 \\
\hline 49.26 & 53.39 & 87 & 7 \\
\hline 44.82 & 57.66 & 118 & 37 \\
\hline
\end{tabular}




\begin{tabular}{|c|c|c|c|c|c|}
\hline 82 & Florida International & 50.74 & 51.56 & 102 & 20 \\
\hline 83 & Rutgers (Camden) & 49.26 & 52.99 & 102 & 19 \\
\hline 84 & Cincinnati & 49.26 & 52.65 & 82 & -2 \\
\hline 85 & Louis ville & 46.30 & 55.03 & 94 & 9 \\
\hline 86 & Loyola (Chicago) & 52.23 & 48.85 & 78 & -8 \\
\hline 87 & Drexel & 47.78 & 52.85 & 127 & 40 \\
\hline 88 & Lew is \& Clark & 53.71 & 46.83 & 94 & 6 \\
\hline 89 & SUNY (Buffalo) & 47.78 & 52.43 & 87 & -2 \\
\hline 90 & Syracuse & 49.26 & 50.79 & 87 & -3 \\
\hline 91 & Pepperdine & 56.67 & 43.15 & 52 & -39 \\
\hline 92 & Drake & 44.82 & 54.81 & 113 & 21 \\
\hline 93 & Denver & 50.74 & 48.80 & 67 & -26 \\
\hline 94 & UC-Hastings & 53.71 & 45.81 & 59 & -35 \\
\hline 95 & Haw aii & 50.74 & 48.70 & 82 & -13 \\
\hline 96 & Texas Tech & 47.78 & 51.40 & 118 & 22 \\
\hline 97 & Connecticut & 52.23 & 46.95 & 63 & -34 \\
\hline 98 & Idaho & 43.34 & 55.62 & 127 & 29 \\
\hline 99 & West Virginia & 47.78 & 50.80 & 94 & -5 \\
\hline 100 & San Diego & 55.19 & 43.28 & 71 & -29 \\
\hline 101 & Washburn & 43.34 & 55.03 & 122 & 21 \\
\hline 102 & Pittsburgh & 52.23 & 46.11 & 78 & -24 \\
\hline 103 & Brooklyn & 50.74 & 47.29 & 78 & -25 \\
\hline 104 & Stetson & 49.26 & 48.72 & 105 & 1 \\
\hline 105 & Chicago-Kent & 52.23 & 45.64 & 78 & -27 \\
\hline 106 & Creighton & 44.82 & 52.76 & 113 & 7 \\
\hline 107 & Missouri (Kansas City) & 44.82 & 52.75 & 127 & 20 \\
\hline 108 & Albany & 43.34 & 53.89 & 138 & 30 \\
\hline 109 & Indiana (Indianapolis) & 44.82 & 51.80 & 102 & -7 \\
\hline 110 & Wayne State & 50.74 & 45.84 & 105 & -5 \\
\hline 111 & South Dakota & 38.89 & 57.33 & 145 & 34 \\
\hline 112 & Campbell & 44.82 & 51.10 & . & . \\
\hline 113 & Mississippi & 49.26 & 46.22 & 94 & -19 \\
\hline 114 & Arkansas (Fayetteville) & 47.78 & 47.54 & 75 & -39 \\
\hline 115 & Hofstra & 44.82 & 49.95 & 122 & 7 \\
\hline 116 & Willamette & 43.34 & 51.39 & 118 & 2 \\
\hline 117 & Duquesne & 44.82 & 49.76 & 118 & 1 \\
\hline 118 & Oregon & 52.23 & 42.20 & 82 & -36 \\
\hline 119 & DePaul & 46.30 & 48.09 & 122 & 3 \\
\hline 120 & Chapman & 50.74 & 43.60 & 127 & 7 \\
\hline 121 & Gonzaga & 46.30 & 47.80 & 110 & -11 \\
\hline 122 & Memphis & 46.30 & 47.51 & 142 & 20 \\
\hline 123 & William Mitchell & 44.82 & 48.32 & 142 & 19 \\
\hline 124 & American & 50.74 & 42.13 & 71 & -53 \\
\hline 125 & Northern Illinois & 41.86 & 50.95 & . & . \\
\hline 126 & South Texas & 43.34 & 49.41 & 149 & 23 \\
\hline 127 & North Dakota & 41.86 & 50.25 & 138 & 11 \\
\hline
\end{tabular}




\begin{tabular}{|c|c|c|c|c|c|}
\hline 128 & Catholic & 49.26 & 42.69 & 108 & -20 \\
\hline 129 & Pace & 43.34 & 48.38 & 138 & 9 \\
\hline 130 & St. Thomas (Minneapolis) & 47.78 & 43.92 & 135 & 5 \\
\hline 131 & Samford & 43.34 & 48.22 & 149 & 18 \\
\hline 132 & CUNY & 47.78 & 43.76 & 113 & -19 \\
\hline 133 & Wyoming & 46.30 & 45.14 & 108 & -25 \\
\hline 134 & Nova Southeastern & 38.89 & 52.40 & . & . \\
\hline 135 & How ard & 43.34 & 47.81 & 110 & -25 \\
\hline 136 & Baltimore & 44.82 & 46.08 & 122 & -14 \\
\hline 137 & Akron & 46.30 & 44.52 & 127 & -10 \\
\hline 138 & Michigan State & 49.26 & 41.50 & 94 & -44 \\
\hline 139 & Southern Illinois & 37.41 & 53.32 & 149 & 10 \\
\hline 140 & Texas A\&M & 47.78 & 42.91 & 149 & 9 \\
\hline 141 & Loyola (New Orleans) & 46.30 & 44.03 & 135 & -6 \\
\hline 142 & Oklahoma City & 38.89 & 51.27 & 149 & 7 \\
\hline 143 & Arkansas (Little Rock) & 41.86 & 48.16 & 135 & -8 \\
\hline 144 & Marquette & 44.82 & 44.98 & 105 & -39 \\
\hline 145 & Seattle & 47.78 & 41.95 & 113 & -32 \\
\hline 146 & Cleveland State & 46.30 & 43.08 & 127 & -19 \\
\hline 147 & Vermont & 44.82 & 44.56 & 122 & -25 \\
\hline 148 & Maine & 46.30 & 43.05 & 110 & -38 \\
\hline 149 & John Marshall (Chicago) & 40.38 & 48.90 & . & . \\
\hline 150 & St. Mary's & 41.86 & 45.96 & . & . \\
\hline 151 & Santa Clara & 52.23 & 35.28 & 94 & -57 \\
\hline 152 & Regent & 44.82 & 42.18 & . & . \\
\hline 153 & Quinnipiac & 46.30 & 39.73 & 127 & -26 \\
\hline 154 & Hamline & 43.34 & 42.58 & 145 & -9 \\
\hline 155 & Touro & 35.93 & 49.22 & . & . \\
\hline 156 & New York Law School & 43.34 & 40.82 & 127 & -29 \\
\hline 157 & Dayton & 38.89 & 45.13 & 145 & -12 \\
\hline 158 & Charleston & 38.89 & 45.11 & . & . \\
\hline 159 & California Western & 41.86 & 41.95 & . & . \\
\hline 160 & Ohio Northern & 41.86 & 41.90 & 145 & -15 \\
\hline 161 & Widener (both campuses) & 40.38 & 43.32 & . & . \\
\hline 162 & McGeorge & 43.34 & 40.19 & . & . \\
\hline 163 & Liberty & 43.34 & 39.17 & . & . \\
\hline 164 & Northern Kentucky & 41.86 & 40.24 & . & . \\
\hline 165 & Mississippi College & 37.41 & 43.83 & . & . \\
\hline 166 & St. Thomas (Miami) & 38.89 & 41.41 & . & . \\
\hline 167 & Roger Williams & 38.89 & 41.38 & . & . \\
\hline 168 & Toledo & 43.34 & 36.79 & 142 & -26 \\
\hline 169 & New England & 41.86 & 37.77 & . & . \\
\hline 170 & Detroit Mercy & 44.82 & 34.70 & . & . \\
\hline 171 & San Francisco & 46.30 & 32.99 & 138 & -33 \\
\hline 172 & Suffolk & 35.93 & 42.86 & . & . \\
\hline 173 & Southw estern & 43.34 & 35.43 & . & \\
\hline
\end{tabular}




$\begin{array}{ll}174 & \text { Valparaiso } \\ 175 & \text { Elon } \\ 176 & \text { John Marshall (Atlanta) } \\ 177 & \text { Barry } \\ 178 & \text { Capital } \\ 179 & \text { Western New England } \\ 180 & \text { Faulkner } \\ 181 & \text { Western State } \\ 182 & \text { North Carolina Central } \\ 183 & \text { Arizona Summit } \\ 184 & \text { Florida A\&M } \\ 185 & \text { Golden Gate } \\ 186 & \text { District of Columbia } \\ 187 & \text { Appalachian } \\ 188 & \text { Ave Maria } \\ 189 & \text { Florida Coastal } \\ 190 & \text { Whittier } \\ 191 & \text { Texas Southern } \\ 192 & \text { Thomas Jefferson } \\ 193 & \text { WMU Thomas M. Cooley } \\ 194 & \text { Southern Univ Law Center } \\ 195 & \text { Charlotte }\end{array}$

\begin{tabular}{|c|c|}
\hline 34.45 & 41.96 \\
\hline 38.89 & 36.86 \\
\hline 38.89 & 36.40 \\
\hline 35.93 & 38.75 \\
\hline 38.89 & 35.11 \\
\hline 35.93 & 36.32 \\
\hline 34.45 & 36.76 \\
\hline 40.38 & 30.19 \\
\hline 32.97 & 36.74 \\
\hline 32.97 & 36.38 \\
\hline 35.93 & 33.13 \\
\hline 40.38 & 27.42 \\
\hline 38.89 & 27.58 \\
\hline 32.97 & 33.44 \\
\hline 31.49 & 34.79 \\
\hline 31.49 & 33.89 \\
\hline 35.93 & 28.63 \\
\hline 34.45 & 29.29 \\
\hline 34.45 & 28.99 \\
\hline 34.45 & 28.75 \\
\hline 32.97 & 29.68 \\
\hline 30.01 & 30.77 \\
\hline
\end{tabular}


Table 4

Schools with Largest Improvement in the LSAT and Employment Rankings over U.S. News Ranking (20 places or more)

\section{School Improvement in Rank}

$\begin{array}{ll}\text { Campbell } & 42 * \\ \text { Drexel } & 40 \\ \text { Montana } & 40 \\ \text { Mercer } & 37 \\ \text { South Dakota } & 34 \\ \text { Albany } & 30 \\ \text { Idaho } & 29 \\ \text { LSU } & 29 \\ \text { Northern Illinois } & 29 * \\ \text { Villanova } & 26 \\ \text { Kentucky } & 25 \\ \text { South Carolina } & 24 \\ \text { South Texas } & 23 \\ \text { Texas Tech } & 22 \\ \text { Drake } & 21 \\ \text { Washburn } & 21 \\ \text { Florida International } & 20 \\ \text { Kansas } & 20 \\ \text { Memphtis } & 20 \\ \text { Missouri (Kansas City) } & 20 \\ \text { New Mexico } & 20 \\ \text { Nova Southeastern } & 20 * \\ & \end{array}$

* Campbell, Northern Illinois, and Nova Southeastern are each unranked by U.S. News, so they have been assigned a U.S. News rank of 154 for purposes of determining the difference between the U.S. News rank and the two variable new rank. 
Table 5

Schools with Largest Decline in the LSAT and Employment Rankings over U.S. News Ranking (20 places or more)

$\begin{array}{ll}\text { School } & \text { Cha } \\ \text { Santa Clara } & -57 \\ \text { American } & -53 \\ \text { Michigan State } & -44 \\ \text { Arkansas-Fayetteville } & -39 \\ \text { Pepperdine } & -39 \\ \text { Marquette } & -39 \\ \text { Oregon } & -36 \\ \text { UC-Hastings } & -35 \\ \text { Connecticut } & -34 \\ \text { San Francisco } & -33 \\ \text { Seattle } & -32 \\ \text { San Diego } & -29 \\ \text { George Mason } & -29 \\ \text { New York Law School } & -29 \\ \text { Chicago-Kent } & -27 \\ \text { Tennessee } & -27 \\ \text { Denver } & -26 \\ \text { Quinnipiac } & -26 \\ \text { Toledo } & -26 \\ \text { Brooklyn } & -25 \\ \text { Howard } & -25 \\ \text { Wyoming } & -25 \\ \text { Vermont } & -25 \\ \text { Pittsburgh } & -20 \\ \text { Utah } & \end{array}$


Table 6

Law Schools Ranked by Mean of

\section{LSAT, Employment, and Citations Rankings}

Rank based on 3 variables (LSAT, employment, and citations), with standard score for each variable plus U.S. News rank and difference between new rank and U.S. News rank

\begin{tabular}{|c|c|c|c|c|c|c|c|}
\hline $\begin{array}{l}\text { Rank } \\
3 \text { var }\end{array}$ & School & $\begin{array}{l}\text { Mean } \\
\text { 3var }\end{array}$ & $\begin{array}{l}\text { LSAT } \\
\text { std }\end{array}$ & $\begin{array}{l}\text { Emp } \\
\text { std }\end{array}$ & $\begin{array}{l}\text { Cites } \\
\text { std }\end{array}$ & $\begin{array}{l}\text { USN } \\
\text { rank }\end{array}$ & $\begin{array}{l}\text { USN rank } \\
\text { - new rank }\end{array}$ \\
\hline 1 & Harvard & 72.50 & 75.93 & 70.55 & 71.03 & 2 & 1 \\
\hline 2 & Columbia & 71.49 & 74.45 & 71.73 & 68.29 & 4 & 2 \\
\hline 3 & Stanford & 71.14 & 74.45 & 70.22 & 68.76 & 2 & -1 \\
\hline 4 & Pennsylvania & 70.95 & 70.00 & 74.67 & 68.19 & 7 & 3 \\
\hline 5 & NYU & 69.32 & 71.48 & 70.91 & 65.56 & 6 & 1 \\
\hline 6 & Duke & 68.98 & 70.00 & 72.24 & 64.70 & 8 & 2 \\
\hline 7 & Virginia & 68.92 & 70.00 & 70.07 & 66.69 & 8 & 1 \\
\hline 8 & Chicago & 68.71 & 71.48 & 71.37 & 63.28 & 4 & -4 \\
\hline 9 & Cornell & 68.44 & 67.04 & 73.75 & 64.54 & 13 & 4 \\
\hline 10 & Yale & 68.14 & 75.93 & 59.37 & 69.12 & 1 & -9 \\
\hline 11 & Michigan & 67.96 & 68.52 & 67.95 & 67.40 & 11 & 0 \\
\hline 12 & UC-Berkeley & 67.75 & 67.04 & 70.21 & 66.01 & 8 & -4 \\
\hline 13 & Northwestern & 66.78 & 68.52 & 65.29 & 66.52 & 12 & -1 \\
\hline 14 & Georgetown & 64.77 & 67.04 & 59.31 & 67.97 & 14 & 0 \\
\hline 15 & Texas & 64.73 & 67.04 & 60.53 & 66.62 & 15 & 0 \\
\hline 16 & UCLA & 64.69 & 67.04 & 60.47 & 66.57 & 16 & 0 \\
\hline 17 & Vanderbilt & 64.59 & 67.04 & 62.64 & 64.08 & 17 & 0 \\
\hline 18 & Minnesota & 63.56 & 62.60 & 61.76 & 66.32 & 20 & 2 \\
\hline 19 & Iowa & 62.16 & 56.67 & 64.78 & 65.03 & 22 & 3 \\
\hline 20 & Fordham & 61.94 & 61.11 & 58.10 & 66.62 & 34 & 14 \\
\hline 21 & Washington (St. Louis) & 61.86 & 65.56 & 61.69 & 58.35 & 18 & -3 \\
\hline 22 & Boston College & 61.50 & 59.63 & 62.73 & 62.14 & 34 & 12 \\
\hline 23 & Boston University & 61.06 & 61.11 & 58.19 & 63.87 & 26 & 3 \\
\hline 24 & Notre Dame & 61.02 & 61.11 & 57.20 & 64.75 & 22 & -2 \\
\hline 25 & George Washington & 60.81 & 64.08 & 56.45 & 61.90 & 22 & -3 \\
\hline 26 & USC & 60.33 & 65.56 & 56.15 & 59.28 & 20 & -6 \\
\hline 27 & William \& Mary & 60.02 & 61.11 & 54.94 & 64.00 & 29 & 2 \\
\hline 28 & North Carolina & 59.66 & 58.15 & 58.78 & 62.06 & 34 & 6 \\
\hline 29 & Emory & 59.46 & 64.08 & 54.80 & 59.49 & 19 & -10 \\
\hline 30 & UC-Davis & 59.33 & 59.63 & 57.06 & 61.31 & 31 & 1 \\
\hline 31 & Alabama & 59.29 & 61.11 & 59.38 & 57.36 & 22 & -9 \\
\hline 32 & Illinois & 58.94 & 58.15 & 55.69 & 62.99 & 41 & 9 \\
\hline 33 & Georgia & 58.79 & 61.11 & 60.12 & 55.15 & 31 & -2 \\
\hline 34 & Indiana (Bloomington) & 58.53 & 58.15 & 55.12 & 62.32 & 34 & 0 \\
\hline
\end{tabular}




\begin{tabular}{|c|c|c|c|c|c|c|c|}
\hline 35 & Washington (Seattle) & 58.51 & 62.60 & 53.36 & 59.58 & 28 & -7 \\
\hline 36 & Ohio State & 57.92 & 55.19 & 61.01 & 57.58 & 34 & -2 \\
\hline 37 & BYU & 57.81 & 59.63 & 57.84 & 55.95 & 34 & -3 \\
\hline 38 & Arizona & 57.75 & 58.15 & 56.36 & 58.73 & 42 & 4 \\
\hline 39 & Wake Forest & 57.70 & 58.15 & 57.46 & 57.49 & 47 & 8 \\
\hline 40 & Florida & 57.58 & 53.71 & 58.47 & 60.56 & 47 & 7 \\
\hline 41 & Washington \& Lee & 57.50 & 58.15 & 55.31 & 59.05 & 42 & 1 \\
\hline 42 & Wisconsin & 57.16 & 58.15 & 55.15 & 58.17 & 31 & -11 \\
\hline 43 & Colorado & 57.04 & 58.15 & 57.33 & 55.64 & 40 & -3 \\
\hline 44 & Arizona State & 56.96 & 59.63 & 58.04 & 53.20 & 26 & -18 \\
\hline 45 & SMU & 56.54 & 58.15 & 57.52 & 53.96 & 46 & 1 \\
\hline 46 & Cardozo & 56.31 & 55.19 & 49.93 & 63.80 & 75 & 29 \\
\hline 47 & Tulane & 56.11 & 58.15 & 53.01 & 57.18 & 50 & 3 \\
\hline 48 & Florida State & 55.27 & 55.19 & 56.90 & 53.72 & 50 & 2 \\
\hline 49 & Houston & 55.18 & 55.19 & 53.86 & 56.50 & 59 & 10 \\
\hline 50 & Kentucky & 54.90 & 49.26 & 66.58 & 48.85 & 63 & 13 \\
\hline 51 & Seton Hall & 54.73 & 50.74 & 60.78 & 52.68 & 63 & 12 \\
\hline 52 & Utah & 54.46 & 53.71 & 54.48 & 55.19 & 42 & -10 \\
\hline 53 & Penn State & 54.34 & 53.71 & 56.00 & 53.30 & 71 & 18 \\
\hline 54 & Miami & 54.26 & 52.23 & 57.39 & 53.15 & 63 & 9 \\
\hline 55 & Missouri (Columbia) & 54.24 & 52.23 & 55.77 & 54.71 & 59 & 4 \\
\hline 56 & Kansas & 54.15 & 53.71 & 56.55 & 52.20 & 67 & 11 \\
\hline 57 & George Mason & 53.92 & 58.15 & 47.16 & 56.44 & 42 & -15 \\
\hline 58 & Georgia State & 53.84 & 53.71 & 58.75 & 49.05 & 56 & -2 \\
\hline 59 & UNLV & 53.70 & 53.71 & 55.48 & 51.93 & 67 & 8 \\
\hline 60 & UC-Irvine & 53.55 & 62.60 & 54.31 & 43.74 & 30 & -30 \\
\hline 61 & UC-Hastings & 53.49 & 53.71 & 45.81 & 60.94 & 59 & -2 \\
\hline 62 & Temple & 53.48 & 56.67 & 52.71 & 51.05 & 52 & -10 \\
\hline 63 & Connecticut & 53.40 & 52.23 & 46.95 & 61.02 & 63 & 0 \\
\hline 64 & Maryland & 53.37 & 55.19 & 50.61 & 54.30 & 47 & -17 \\
\hline 65 & Loyola (Los Angeles) & 53.36 & 55.19 & 50.95 & 53.95 & 75 & 10 \\
\hline 66 & Richmond & 53.35 & 56.67 & 49.64 & 53.73 & 52 & -14 \\
\hline 67 & Lew is \& Clark & 53.10 & 53.71 & 46.83 & 58.75 & 94 & 27 \\
\hline 68 & Villanova & 53.09 & 52.23 & 56.16 & 50.89 & 87 & 19 \\
\hline 69 & Nebraska & 52.78 & 50.74 & 57.33 & 50.26 & 56 & -13 \\
\hline 70 & South Carolina & 52.75 & 49.26 & 56.06 & 52.93 & 94 & 24 \\
\hline 71 & LSU & 52.69 & 49.26 & 58.56 & 50.23 & 94 & 23 \\
\hline 72 & Cincinnati & 52.56 & 49.26 & 52.65 & 55.76 & 82 & 10 \\
\hline 73 & St. Louis & 52.51 & 49.26 & 53.39 & 54.89 & 87 & 14 \\
\hline 74 & Baylor & 52.44 & 55.19 & 57.50 & 44.62 & 56 & -18 \\
\hline 75 & Case Western & 52.09 & 55.19 & 48.56 & 52.51 & 59 & -16 \\
\hline 76 & Rutgers (Newark) & 51.84 & 50.74 & 53.83 & 50.96 & 87 & 11 \\
\hline 77 & St. John's & 51.67 & 52.23 & 53.15 & 49.64 & 82 & 5 \\
\hline 78 & Tennessee & 51.67 & 53.71 & 49.12 & 52.18 & 52 & -26 \\
\hline 79 & Oklahoma & 51.57 & 52.23 & 57.17 & 45.30 & 67 & -12 \\
\hline 80 & SUNY (Buffalo) & 51.56 & 47.78 & 52.43 & 54.47 & 87 & 7 \\
\hline
\end{tabular}




\begin{tabular}{|c|c|}
\hline 81 & Pepperdine \\
\hline 82 & Northeastern \\
\hline 83 & New Mexico \\
\hline 84 & Brooklyn \\
\hline 85 & Loyola (Chic ago) \\
\hline 86 & Denver \\
\hline 87 & Tulsa \\
\hline 88 & Chicago-Kent \\
\hline 89 & Mercer \\
\hline 90 & San Diego \\
\hline 91 & DePaul \\
\hline 92 & American \\
\hline 93 & Albany \\
\hline 94 & Louis ville \\
\hline 95 & Hofstra \\
\hline 96 & Drake \\
\hline 97 & Indiana (Indianapolis) \\
\hline 98 & Texas Tech \\
\hline 99 & Washburn \\
\hline 100 & Syracuse \\
\hline 101 & Missouri (Kansas City) \\
\hline 102 & Rutgers (Camden) \\
\hline 103 & West Virginia \\
\hline 104 & Oregon \\
\hline 105 & William Mitchell \\
\hline 106 & Pittsburgh \\
\hline 107 & Michigan State \\
\hline 108 & Creighton \\
\hline 109 & Missis sippi \\
\hline 110 & Montana \\
\hline 111 & Akron \\
\hline 112 & Seattle \\
\hline 113 & Drexel \\
\hline 114 & Idaho \\
\hline 115 & Wayne State \\
\hline 116 & Marquette \\
\hline 117 & Stetson \\
\hline 118 & Catholic \\
\hline 119 & New Hampshire \\
\hline 120 & Pace \\
\hline 121 & Arkansas (Fayetteville) \\
\hline 122 & Willamette \\
\hline 123 & How ard \\
\hline 124 & Memphis \\
\hline 125 & Vermont \\
\hline 126 & Santa Clara \\
\hline
\end{tabular}

\begin{tabular}{|c|c|c|c|c|c|}
\hline 51.49 & 56.67 & 43.15 & 54.65 & 52 & -29 \\
\hline 51.45 & 58.15 & 45.96 & 50.24 & 87 & 5 \\
\hline 51.26 & 46.30 & 65.55 & 41.93 & 71 & -12 \\
\hline 51.00 & 50.74 & 47.29 & 54.96 & 78 & -6 \\
\hline 50.99 & 52.23 & 48.85 & 51.89 & 78 & -7 \\
\hline 50.94 & 50.74 & 48.80 & 53.27 & 67 & -19 \\
\hline 50.55 & 47.78 & 56.38 & 47.49 & 82 & -5 \\
\hline 50.44 & 52.23 & 45.64 & 53.47 & 78 & -10 \\
\hline 50.43 & 44.82 & 57.66 & 48.80 & 118 & 29 \\
\hline 50.31 & 55.19 & 43.28 & 52.47 & 71 & -19 \\
\hline 50.19 & 46.30 & 48.09 & 56.18 & 122 & 31 \\
\hline 50.18 & 50.74 & 42.13 & 57.66 & 71 & -21 \\
\hline 50.12 & 43.34 & 53.89 & 53.12 & 138 & 45 \\
\hline 50.08 & 46.30 & 55.03 & 48.92 & 94 & 0 \\
\hline 49.79 & 44.82 & 49.95 & 54.60 & 122 & 27 \\
\hline 49.77 & 44.82 & 54.81 & 49.68 & 113 & 17 \\
\hline 49.70 & 44.82 & 51.80 & 52.48 & 102 & 5 \\
\hline 49.69 & 47.78 & 51.40 & 49.89 & 118 & 20 \\
\hline 49.56 & 43.34 & 55.03 & 50.31 & 122 & 23 \\
\hline 49.55 & 49.26 & 50.79 & 48.61 & 87 & -13 \\
\hline 49.51 & 44.82 & 52.75 & 50.97 & 127 & 26 \\
\hline 49.46 & 49.26 & 52.99 & 46.14 & 102 & 0 \\
\hline 49.43 & 47.78 & 50.80 & 49.69 & 94 & -9 \\
\hline 48.81 & 52.23 & 42.20 & 51.99 & 82 & -22 \\
\hline 48.80 & 44.82 & 48.32 & 53.28 & 142 & 37 \\
\hline 48.62 & 52.23 & 46.11 & 47.54 & 78 & -28 \\
\hline 48.50 & 49.26 & 41.50 & 54.75 & 94 & -13 \\
\hline 48.38 & 44.82 & 52.76 & 47.57 & 113 & 5 \\
\hline 48.20 & 49.26 & 46.22 & 49.12 & 94 & -15 \\
\hline 48.02 & 47.78 & 57.04 & 39.23 & 113 & 3 \\
\hline 47.93 & 46.30 & 44.52 & 52.98 & 127 & 16 \\
\hline 47.90 & 47.78 & 41.95 & 53.99 & 113 & 1 \\
\hline 47.72 & 47.78 & 52.85 & 42.54 & 127 & 14 \\
\hline 47.57 & 43.34 & 55.62 & 43.74 & 127 & 13 \\
\hline 47.52 & 50.74 & 45.84 & 45.96 & 105 & -10 \\
\hline 47.41 & 44.82 & 44.98 & 52.42 & 105 & -11 \\
\hline 47.29 & 49.26 & 48.72 & 43.89 & 105 & -12 \\
\hline 47.24 & 49.26 & 42.69 & 49.77 & 108 & -10 \\
\hline 47.18 & 49.26 & 54.55 & 37.72 & 87 & -32 \\
\hline 47.12 & 43.34 & 48.38 & 49.64 & 138 & 18 \\
\hline 47.10 & 47.78 & 47.54 & 45.98 & 75 & -46 \\
\hline 46.80 & 43.34 & 51.39 & 45.66 & 118 & -4 \\
\hline 46.69 & 43.34 & 47.81 & 48.93 & 110 & -13 \\
\hline 46.67 & 46.30 & 47.51 & 46.20 & 142 & 18 \\
\hline 46.60 & 44.82 & 44.56 & 50.42 & 122 & -3 \\
\hline 46.53 & 52.23 & 35.28 & 52.08 & 94 & -32 \\
\hline
\end{tabular}




\begin{tabular}{|c|c|}
\hline 127 & Duquesne \\
\hline 128 & South Dakota \\
\hline 129 & Gonzaga \\
\hline 130 & Campbell \\
\hline 131 & Chapman \\
\hline 132 & Florida International \\
\hline 133 & Cleveland State \\
\hline 134 & South Texas \\
\hline 135 & John Marshall (Chicago) \\
\hline 136 & New York Law School \\
\hline 137 & St. Thomas (Minneapolis) \\
\hline 138 & Haw aii \\
\hline 139 & North Dakota \\
\hline 140 & Widener (both campuses) \\
\hline 141 & Southern Illinois \\
\hline 142 & Maine \\
\hline 143 & Baltimore \\
\hline 144 & Loyola (New Orleans) \\
\hline 145 & Wyoming \\
\hline 146 & McGeorge \\
\hline 147 & Nova Southeastern \\
\hline 148 & Ohio Northern \\
\hline 149 & Quinnipiac \\
\hline 150 & Texas A\&M \\
\hline 151 & Samford \\
\hline 152 & Northern Illinois \\
\hline 153 & Arkansas (Little Rock) \\
\hline 154 & St. Mary's \\
\hline 155 & San Francisco \\
\hline 156 & Toledo \\
\hline 157 & CUNY \\
\hline 158 & Oklahoma City \\
\hline 159 & Regent \\
\hline 160 & Touro \\
\hline 161 & Hamline \\
\hline 162 & Suffolk \\
\hline 163 & Charleston \\
\hline 164 & Southw estern \\
\hline 165 & New England \\
\hline 166 & California Western \\
\hline 167 & Valparaiso \\
\hline 168 & Northern Kentucky \\
\hline 169 & Dayton \\
\hline 170 & Roger Williams \\
\hline 171 & St. Thomas (Miami) \\
\hline 172 & Detroit Mercy \\
\hline
\end{tabular}

\begin{tabular}{|c|c|c|c|c|c|}
\hline 46.44 & 44.82 & 49.76 & 44.73 & 118 & -9 \\
\hline 46.40 & 38.89 & 57.33 & 42.98 & 145 & 17 \\
\hline 46.34 & 46.30 & 47.80 & 44.91 & 110 & -19 \\
\hline 46.25 & 44.82 & 51.10 & 42.82 & . & . \\
\hline 46.04 & 50.74 & 43.60 & 43.79 & 127 & -4 \\
\hline 45.94 & 50.74 & 51.56 & 35.53 & 102 & -30 \\
\hline 45.75 & 46.30 & 43.08 & 47.89 & 127 & -6 \\
\hline 45.75 & 43.34 & 49.41 & 44.51 & 149 & 15 \\
\hline 45.68 & 40.38 & 48.90 & 47.77 & . & . \\
\hline 45.43 & 43.34 & 40.82 & 52.13 & 127 & -9 \\
\hline 45.37 & 47.78 & 43.92 & 44.41 & 135 & -2 \\
\hline 45.36 & 50.74 & 48.70 & 36.63 & 82 & -56 \\
\hline 45.12 & 41.86 & 50.25 & 43.25 & 138 & -1 \\
\hline 44.97 & 40.38 & 43.32 & 51.23 & . & . \\
\hline 44.96 & 37.41 & 53.32 & 44.15 & 149 & 8 \\
\hline 44.83 & 46.30 & 43.05 & 45.15 & 110 & -32 \\
\hline 44.61 & 44.82 & 46.08 & 42.93 & 122 & -21 \\
\hline 44.53 & 46.30 & 44.03 & 43.28 & 135 & -9 \\
\hline 44.34 & 46.30 & 45.14 & 41.59 & 108 & -37 \\
\hline 44.15 & 43.34 & 40.19 & 48.92 & . & . \\
\hline 43.75 & 38.89 & 52.40 & 39.96 & . & . \\
\hline 43.75 & 41.86 & 41.90 & 47.49 & 145 & -3 \\
\hline 43.73 & 46.30 & 39.73 & 45.15 & 127 & -22 \\
\hline 43.62 & 47.78 & 42.91 & 40.18 & 149 & -1 \\
\hline 43.62 & 43.34 & 48.22 & 39.31 & 149 & -2 \\
\hline 43.62 & 41.86 & 50.95 & 38.04 & . & . \\
\hline 43.57 & 41.86 & 48.16 & 40.70 & 135 & -18 \\
\hline 43.46 & 41.86 & 45.96 & 42.57 & . & . \\
\hline 43.37 & 46.30 & 32.99 & 50.81 & 138 & -17 \\
\hline 43.31 & 43.34 & 36.79 & 49.80 & 142 & -14 \\
\hline 43.28 & 47.78 & 43.76 & 38.31 & 113 & -44 \\
\hline 43.25 & 38.89 & 51.27 & 39.58 & 149 & -9 \\
\hline 43.08 & 44.82 & 42.18 & 42.25 & . & . \\
\hline 43.02 & 35.93 & 49.22 & 43.91 & . & . \\
\hline 42.93 & 43.34 & 42.58 & 42.87 & 145 & -16 \\
\hline 42.59 & 35.93 & 42.86 & 48.98 & . & . \\
\hline 42.48 & 38.89 & 45.11 & 43.43 & . & . \\
\hline 42.29 & 43.34 & 35.43 & 48.11 & . & . \\
\hline 42.20 & 41.86 & 37.77 & 46.96 & . & . \\
\hline 42.02 & 41.86 & 41.95 & 42.25 & . & . \\
\hline 41.78 & 34.45 & 41.96 & 48.92 & . & . \\
\hline 41.56 & 41.86 & 40.24 & 42.60 & $\cdot$ & . \\
\hline 41.41 & 38.89 & 45.13 & 40.21 & 145 & -24 \\
\hline 40.78 & 38.89 & 41.38 & 42.08 & . & . \\
\hline 40.70 & 38.89 & 41.41 & 41.80 & . & . \\
\hline 40.33 & 44.82 & 34.70 & 41.46 & . & . \\
\hline
\end{tabular}




$\begin{array}{ll}173 & \text { Capital } \\ 174 & \text { Mississippi College } \\ 175 & \text { Western New England } \\ 176 & \text { Liberty } \\ 177 & \text { Barry } \\ 178 & \text { Golden Gate } \\ 179 & \text { Ave Maria } \\ 180 & \text { Arizona Summit } \\ 181 & \text { Western State } \\ 182 & \text { John Marshall (Atlanta) } \\ 183 & \text { Whittier } \\ 184 & \text { North Carolina Central } \\ 185 & \text { Florida Coastal } \\ 186 & \text { Thomas Jefferson } \\ 187 & \text { Elon } \\ 188 & \text { Appalachian } \\ 189 & \text { Southern Univ Law Center } \\ 190 & \text { District of Columbia } \\ 191 & \text { WMU Thomas M. Cooley } \\ 192 & \text { Faulkner } \\ 193 & \text { Texas Southern } \\ 194 & \text { Florida A\&M } \\ 195 & \text { Charlotte }\end{array}$

$\begin{array}{llll}39.85 & 38.89 & 35.11 & 45.56 \\ 39.65 & 37.41 & 43.83 & 37.72 \\ 38.69 & 35.93 & 36.32 & 43.81 \\ 37.83 & 43.34 & 39.17 & 30.97 \\ 37.73 & 35.93 & 38.75 & 38.52 \\ 35.34 & 40.38 & 27.42 & 38.22 \\ 35.15 & 31.49 & 34.79 & 39.19 \\ 34.69 & 32.97 & 36.38 & 34.73 \\ 34.67 & 40.38 & 30.19 & 33.44 \\ 34.61 & 38.89 & 36.40 & 28.53 \\ 34.60 & 35.93 & 28.63 & 39.23 \\ 34.43 & 32.97 & 36.74 & 33.59 \\ 34.19 & 31.49 & 33.89 & 37.19 \\ 33.66 & 34.45 & 28.99 & 37.53 \\ 33.05 & 38.89 & 36.86 & 23.39 \\ 32.33 & 32.97 & 33.44 & 30.59 \\ 32.29 & 32.97 & 29.68 & 34.21 \\ 32.26 & 38.89 & 27.58 & 30.29 \\ 32.07 & 34.45 & 28.75 & 33.00 \\ 31.80 & 34.45 & 36.76 & 24.18 \\ 31.31 & 34.45 & 29.29 & 30.19 \\ 30.53 & 35.93 & 33.13 & 22.53 \\ 28.68 & 30.01 & 30.77 & 25.26\end{array}$


Table 7

Schools with Largest Improvement in the New Rankings

(Twenty or more places)

$\begin{array}{ll}\text { School } & \text { Impro } \\ \text { Albany } & 45 \\ \text { William Mitchell } & 37 \\ \text { DePaul } & 31 \\ \text { Mercer } & 29 \\ \text { Hofstra } & 27 \\ \text { Lew is \& Clark } & 27 \\ \text { Missouri-Kansas City } & 26 \\ \text { Campbell } & 24 * \\ \text { South Carolina } & 24 \\ \text { LSU } & 23 \\ \text { Washburn } & 23\end{array}$

* Campbell is unranked by U.S. News, so it has been assigned a rank of 154 for purposes of determining the difference between its U.S. News rank and the three variable new rank.

Table 8

Schools with the Largest Decline in the New Rankings

(Twenty or more places)

$\begin{array}{ll}\text { School } & \text { Decline in New Rankings } \\ \text { Hawaii } & -56 \\ \text { Arkansas-Fayetteville } & -46 \\ \text { CUNY } & -44 \\ \text { Wyoming } & -37 \\ \text { Maine } & -32 \\ \text { New Hampshire } & -32 \\ \text { Santa Clara } & -32 \\ \text { UC-Irvine } & -30 \\ \text { Florida International } & -30 \\ \text { Pepperdine } & -29 \\ \text { Pittsburgh } & -28 \\ \text { Tennessee } & -26 \\ \text { Dayton } & -24 \\ \text { Oregon } & -22 \\ \text { Quinnipiac } & -22 \\ \text { Baltimore } & -21\end{array}$


Table 9

Correlations between LSAT Standard Score,

Employed at Ten Months Standard Score, Law Review Citations Standard Score, Two and Three Variable Scores, U.S. News Peer Assessment

195 ABA-Approved Schools

$\begin{array}{lclllll} & \text { LSAT } & \text { Emp } & \text { cites } & \text { sum } & \text { sum } & \text { U.S. News } \\ & \text { std } & \text { std } & \text { std } & \text { 2var } & \text { 3var } & \text { Peer } \\ \text { LSAT std 50,10 } & -- & .78 & .84 & .94 & .95 & .95 \\ \text { Emp std 50,10 } & .78 & -- & .72 .94 & & .90 & .80 \\ \text { log cites std 50,10 } & .84 & .72 & -- & .83 & .92 & .87 \\ \text { Sum 2var } & .94 & .94 & .83 & -- & .98 & .92 \\ \text { Sum 3var } & .95 & .90 & .92 & .98 & -- & .94 \\ \text { U.S. News Peer } & .95 & .80 & .87 & .92 & .94 & -- \\ \text { N = 195 } & & & & & & \end{array}$

All correlations: $\mathrm{p}<.0001$

Table 10

Correlations between LSAT Standard Score,

Employed at Ten Months Standard Score, Law Review Citations Standard Score, Two and Three Variable Scores, U.S. News Peer Assessment and Rank, for 153 U.S. News Ranked Schools

\begin{tabular}{lcllllll} 
& \multicolumn{9}{c}{ LSAT } & Emp & cites & sum & sum & & USN \\
& std & std & std & 2var & 3 var & Peer & rank \\
LSAT std 50,10 & -- & .68 & .81 & .92 & .93 & .95 & -.93 \\
Emp std 50,10 & .68 & -- & .57 & .91 & .84 & .73 & -.71 \\
log cites std 50,10 & .81 & .57 & -- & .75 & .89 & .85 & -.80 \\
Sum 2var & .92 & .91 & .75 & -- & .97 & .92 & -.90 \\
Sum 3var & .93 & .84 & .89 & .97 & -- & .95 & -.91 \\
Peer & .95 & .73 & .85 & .92 & .95 & -- & -.91 \\
USN rank & -.93 & -.71 & -.80 & -.90 & -.91 & -.91 & -- \\
N = 153 & & & & & & &
\end{tabular}

All correlations: $\mathrm{p}<.0001$ 